\title{
Anderson-type Polyoxometalates Functionalized by \\ Tetrathiafulvalene Groups: Synthesis, Electrochemical Studies and NLO Properties
}

Amandine Boulmier, ${ }^{\dagger}$ Antoine Vacher, ${ }^{\ddagger}$ Dejin Zang, ${ }^{\S}$ Shu Yang, ${ }^{\S}$ Ali Saad, ${ }^{\dagger}$ Jérôme Marrot, ${ }^{\dagger}$ Olivier Oms, ${ }^{\dagger}$ Pierre Mialane, ${ }^{\dagger}$ Isabelle Ledoux, $\|$ Laurent Ruhlmann, ${ }^{*}$, Dominique Lorcy, ${ }^{\dagger}$ and Anne Dolbecq ${ }^{*}{ }^{\dagger}$

† Institut Lavoisier de Versailles, UMR 8180, Université de Versailles Saint-Quentin en Yvelines, Université Paris-Saclay, 45 Avenue des Etats-Unis, 78035 Versailles cedex, France.

*Univ Rennes, CNRS, ISCR (Institut des Sciences Chimiques de Rennes)-UMR 6226, F-35000 Rennes, France.

${ }^{\S}$ Institut de Chimie, Laboratoire d'Electrochimie et de Chimie Physique du Corps Solide, UMR CNRS 7177, Université de Strasbourg, 4 rue Blaise Pascal, CS 90032, 67081 Strasbourg cedex, France.

॥ ENS Paris Saclay, Laboratoire de Photonique Quantique Moléculaire, UMR ENS CNRS 8537, CentraleSupelec, 61 Avenue du Président Wilson, 94235 Cachan, France. 


\section{ABSTRACT}

Three polyoxometalates (POMs) functionalized by tetrathiafulvalene (TTF) molecules have been synthesized by a coupling reaction between the Anderson-type POMs $\left[\mathrm{MnMo}_{6} \mathrm{O}_{18}\left\{\left(\mathrm{OCH}_{2}\right)_{3} \mathrm{CNH}_{2}\right\}_{2}\right]^{3-}$ or $\left[\mathrm{AlMo}_{6} \mathrm{O}_{18}(\mathrm{OH})_{3}\left\{\left(\mathrm{OCH}_{2}\right)_{3} \mathrm{CNH}_{2}\right\}\right]^{3-}$ and the TTF carboxylic acid derivative $(\mathrm{MeS})_{3} \mathrm{TTF}\left(\mathrm{S}-\mathrm{CH}_{2}-\mathrm{CO}_{2} \mathrm{H}\right)$. The monofunctionalized TTF-AIMo6 POM contains one TTF group covalently grafted on an Al Anderson platform. The symmetrical TTF-MnMo6-TTF POM possesses two TTF groups grafted on each side of a Mn Anderson derivative while the asymmetrical TTF-MnMo6-SP POM contains a TTF and a spiropyran groups. These three trianionic species have been characterized by elemental analysis, ${ }^{1} \mathrm{H}$ and

${ }^{13} \mathrm{C}$ NMR, FT-IR spectroscopy, ESI-MS spectrometry and single-crystal X-ray diffraction (for TTF-MnMo6-TTF). In the solid state, the grafted TTF molecules of the TTF-MnMo6-TTF POMs interact via $\mathrm{S}^{\cdots} \mathrm{S}$ and $\pi^{\cdots} \pi$ interactions and form chains. The electrochemical properties of the complexes reflect the contributions of both the inorganic POM and the TTF moieties. Despite adsorption of the oxidized hybrid species on the Pt grid working electrode, UV-VisNIR spectroelectrochemical investigations evidence peaks characteristic of the oxidation of the TTF units. Finally, Hyper-Rayleigh scattering (HRS) measurements show that the three novel TTF derivatives exhibit $\beta$ values between 20 and $37 \times 10^{-30}$ esu. Moreover it is observed that the oxidation of the TTF moieties by $\mathrm{Fe}^{3+}$ ions increases the NLO response. These values are in the order of magnitude of that found for the well-known 4-dimethylamino-N-methyl-4stilbazolium $\left(\mathrm{DAS}^{+}\right)$cation $\left(\beta=60 \times 10^{-30} \mathrm{esu}\right)$. 


\section{INTRODUCTION}

Polyoxometalates (POMs) constitute a class of discrete anionic oxide metal-oxygen clusters often considered as soluble oxide fragments. They are built from the connection of $\left\{\mathrm{MO}_{\mathrm{x}}\right\}$ polyhedra, $\mathrm{M}$ being a d-block transition metal ion in high oxidation state, usually $\mathrm{W}^{\mathrm{VI}}$, $\mathrm{Mo}^{\mathrm{V}, \mathrm{VI}}$ or $\mathrm{V}^{\mathrm{IV}, \mathrm{V}}{ }^{1}$ Their intrinsic properties such as catalytic and redox activities have attracted significant attention for several decades. ${ }^{2}$ The association of POMs with organic molecules through covalent linkage or via electrostatic interactions allows the development of a vast family of multifunctional inorganic-organic hybrid compounds and significantly extends their range of applications. ${ }^{3}$ We can mention for example the covalent grafting of an $\mathrm{Ir}^{\mathrm{III}}$ complex on a polyoxotungstate which brings photocatalytic activity to the POM. ${ }^{4}$ Another example is the incorporation of bisphosphonates in polyoxomolybdates; these complexes exhibit enhanced activity against breast cancer cell lines compared to the organic and inorganic precursors. ${ }^{5}$ Among these properties, $2^{\text {nd }}$ order non linear optical (NLO) properties have only been the subject of a few theoretical ${ }^{6}$ and experimental studies, either using Hyper-Rayleigh scattering $(\mathrm{HRS})^{7}$ or powder second harmonic generation (SHG) measurements. ${ }^{8}$ An attractive platform for the rational design of molecular organic-inorganic hybrids is the Anderson-type POM. ${ }^{9}$ Indeed, its functionalization has afforded a large variety of symmetrical ${ }^{10}$ or asymmetrical ${ }^{11}$ hybrid POMs with applications ranging from Li batteries ${ }^{12}$ to light driven hydrogen evolution ${ }^{13}$ and cancer therapy. ${ }^{14} \mathrm{~A}$ great advantage of these hybrids is also their possible postfunctionalization. ${ }^{15}$ Our contribution to this field of research consists in the development of a new class of photoactive hybrid molecules based on the association of Anderson-type POMs and spiropyrans (SPs), a well-known family of photochromic molecules. These organic molecules can switch from a colorless closed form to a highly colored merocyanine form under UV irradiation. The asymmetrical $\left[\mathrm{MnMo}_{6} \mathrm{O}_{18}\left\{\left(\mathrm{OCH}_{2}\right)_{3} \mathrm{CNHC}_{21} \mathrm{H}_{19} \mathrm{~N}_{2} \mathrm{O}_{4}\right\}\left\{\left(\mathrm{OCH}_{2}\right)_{3} \mathrm{CNH}_{2}\right\}\right]^{3-}$ $\left(\mathrm{H}_{2} \mathrm{~N}-\mathrm{MnMo}_{6}-\mathrm{SP}\right)$ and symmetrical SP-MnMo6-SP molecules have been isolated by peptide 
coupling reactions using $\mathrm{SPCO}_{2} \mathrm{H}$ and the amino functionalized Anderson POM $\left[\mathrm{MnMo}_{6} \mathrm{O}_{18}\left\{\left(\mathrm{OCH}_{2}\right)_{3} \mathrm{CNH}_{2}\right\}_{2}\right]^{3-}\left(\mathrm{H}_{2} \mathrm{~N}-\mathrm{MnMo}_{6}-\mathrm{NH}_{2}\right) .{ }^{16}$ The asymmetrical molecule is of great interest due to its free amino group allowing further post-functionalization and giving access to multifunctional molecules. ${ }^{17}$

An attractive functional organic molecule to be grafted on a POM platform is the tetrathiafulvalene (TTF). TTF is one of the most well known organic donor molecule. It possesses accessible redox potentials and stable cation radical states, TTF-based radical salts exhibiting attractive properties such as conductivity, ferromagnetism or catalytic activity. ${ }^{18}$ TTF can also display efficient NLO responses in the second and third order harmonic generation. ${ }^{19}$ Several supramolecular assemblies of POMs and TTF radical cations have been reported. ${ }^{20,21}$ The presence of POMs, which act as bulky counter-ions and possess a large diversity of size and shape, has a great influence on the crystal packing but magnetic or electronic interactions between the anionic and cationic components have been only rarely encountered. The conduction mechanism within the hybrid salt (TT-TTF) 3 [PMo12 $\left.\mathrm{P}_{40}\right]$ (TT$\mathrm{TTF}=$ tetra(thienylthio)-tetrathiafulvalene) was for example described as thermally activated electron hopping between mixed valence POMs and TTFs substituted with pyridinium. ${ }^{22}$ Interactions between the electrons from $\mathrm{TTF}^{+}$radical cations and electrons on the $\mathrm{V}^{\mathrm{IV}}$ site of the POM in the charge-transfer material $\mathrm{TTF}_{4}\left[\mathrm{SVW}_{11} \mathrm{O}_{40}\right]$ have also been proposed. ${ }^{23}$ To our knowledge, all the associations of POMs and TTFs described in the literature are ionic associations and besides the recent report of a molecular triad with a bis(terpyridine) $\mathrm{Ru}^{\mathrm{II}}$ complex connected on one side to an extended tetrathiafulvalene moiety and on the other side to a Keggin type POM,${ }^{24}$ the covalent coupling of a TTF and a POM has never been reported to date. It can however be noted that the coupling of an electroactive organic molecule and a POM was already successfully achieved in the $\left[\mathrm{Mo}_{6} \mathrm{O}_{18}(\mathrm{AMBTH})\right]^{2-}$ and $\left[\mathrm{Mo}_{6} \mathrm{O}_{18}(\mathrm{MBTH})\right]^{2-}$ hybrids where AMBTH and MBTH are benzothiazole hydrazone derivatives. ${ }^{25}$ 
Here, we describe the synthesis and characterization of three new compounds associating via covalent bonds an Anderson POM platform and TTF organic molecules and in one case an additional SP moiety. Their electrochemical and spectroelectrochemical properties have been thoroughly investigated together with their second order non-linear optical properties.

\section{RESULTS AND DISCUSSION}

Anderson-type POMs are built of six edge-sharing $\mathrm{MoO}_{6}$ octahedra surrounding a central templating edge-sharing octahedrally coordinated heteroatom, $\mathrm{Cr}^{\mathrm{III}}, \mathrm{Mn}^{\mathrm{III}}$ and $\mathrm{Al}^{\mathrm{III}}$ being the most studied heterometals. A variety of organic tris(hydroxymethyl)methane ligands $\left(\mathrm{RC}\left(\mathrm{CH}_{2} \mathrm{OH}\right)_{3}\right)$ can be grafted on these planar POMs, giving access to functionalized POMs. ${ }^{9-}$ 17 Three POM/TTF derivatives were targeted in this study using Anderson-type POMs precursors: i) the monofunctionalized TTF-AIMos POM that contains one TTF group covalently grafted on an Al Anderson type anion, ii) the symmetrical TTF-MnMo6-TTF POM with one TTF group on each side of a Mn Anderson type anion and iii) the asymmetrical TTFMnMo6-SP POM that derives from our previously reported $\mathrm{H}_{2} \mathrm{~N}-\mathrm{MnMo}$-SP POM. ${ }^{16}$ These POMs were synthesized by a coupling reaction between a carboxylic acid derivative of the TTF molecule and the amino functionalized Anderson type POMs (Figure 1). It should be noted that the three hybrids are trianionic species. 

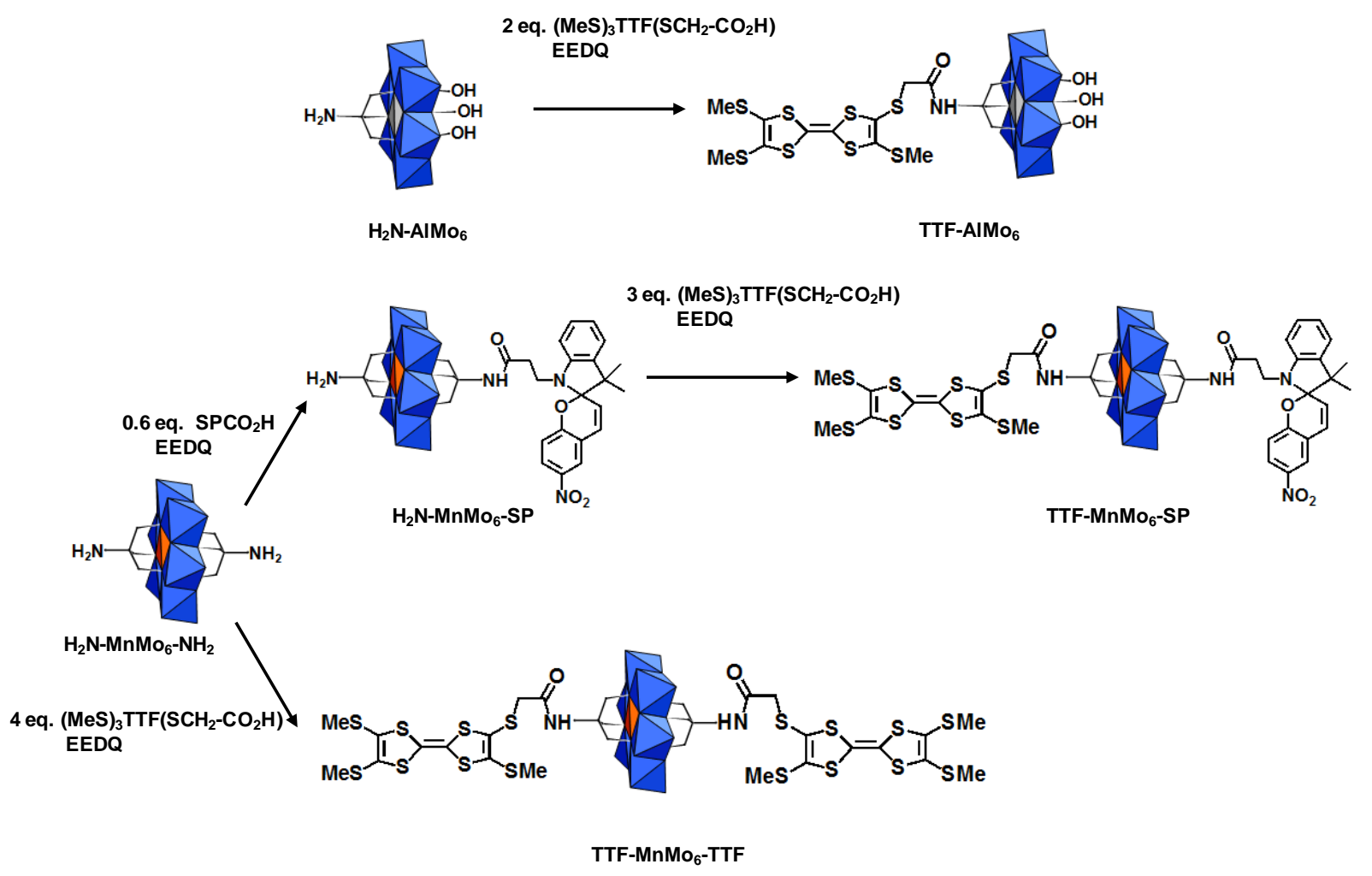

Figure 1. Schematic representation, abbreviation and synthetic procedures for the three POMs functionalized by TTF groups (all with a 3- charge). Blue octahedra $=\mathrm{MoO}_{6}$, orange octahedra $=\mathrm{MnO}_{6}$, gray octahedra $=\mathrm{AlO}_{6}$.

Synthesis and Characterization. The synthesis of the TTF precursor, $(\mathrm{MeS})_{3} \mathrm{TTF}(\mathrm{S}-$ $\left.\mathrm{CH}_{2}-\mathrm{CO}_{2} \mathrm{H}\right)$, was performed following a reported procedure. ${ }^{26}$ Crystals of $(\mathrm{MeS})_{3} \mathrm{TTF}\left(\mathrm{S}-\mathrm{CH}_{2}-\right.$ $\mathrm{CO}_{2} \mathrm{H}$ ) were obtained by recrystallization in $\mathrm{CH}_{2} \mathrm{Cl}_{2}$ and the structure solved by single crystal $\mathrm{X}$-ray diffraction. The compound crystallizes in the monoclinic $C 2 / \mathrm{c}$ space group (Table $\mathrm{S} 1$ ) instead of the orthorhombic Pbcn group reported previously. ${ }^{26}$ The two heterocycles are almost coplanar (Figures 2a and b, Table S2). The molecules are associated into dimers via strong O$\mathrm{H}^{\cdots} \mathrm{O}$ hydrogen bonds (Figure $2 \mathrm{c}$ ) forming the classical eight-membered ring noted $\mathrm{R}_{2}^{2}(8)$ in 
Etter's nomenclature. ${ }^{27}$ Such association is common for monocarboxylic acid derivatives of TTF such as for example (Me) $)_{3}$ TTF- $\mathrm{CO}_{2} \mathrm{H},{ }^{28}$ EDT-TTF- $\mathrm{CO}_{2} \mathrm{H}^{29}$ and EDO-TTF-CO ${ }_{2} \mathrm{H} .{ }^{30}$

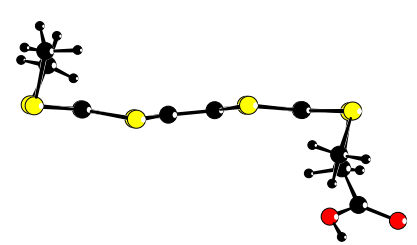

a)

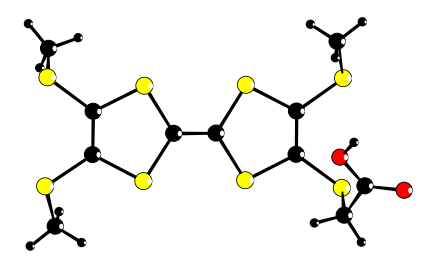

b)

$0 \cdots=2.66(4) \AA$

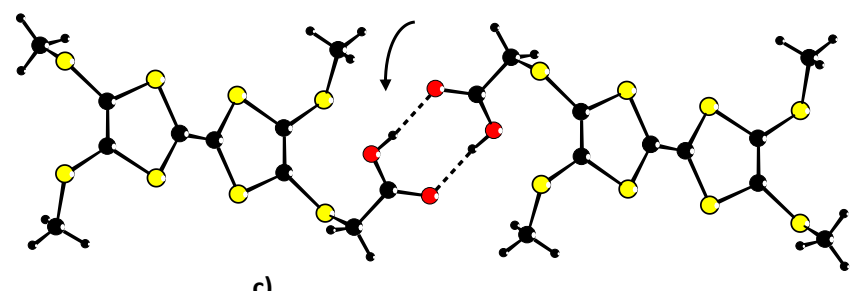

c)

Figure 2. Molecular structure of $(\mathrm{MeS})_{3} \mathrm{TTF}\left(\mathrm{S}-\mathrm{CH}_{2}-\mathrm{CO}_{2} \mathrm{H}\right)$; a) side view, b) top view, c) hydrogen-bonded dimer; black spheres $=\mathrm{C}$, red spheres $=\mathrm{O}$, yellow spheres $=\mathrm{S}$, small black spheres $=\mathrm{H}$.

The monofunctionalized TTF-AIMor POM was isolated by a peptide coupling reaction using the tris-functionalized $\mathrm{H}_{2} \mathrm{~N}-\mathrm{AlMo}{ }_{6} \mathrm{POM}^{31}$ and a two fold excess of the carboxylic derivative of the TTF molecule $\left(\mathrm{Me}_{3} \mathrm{~S}\right)_{3} \mathrm{TTF}\left(\mathrm{S}-\mathrm{CH}_{2}-\mathrm{CO}_{2} \mathrm{H}\right)$ (Figure 1). Similar coupling reactions allowed isolating the symmetrical TTF-MnMo6-TTF and the unsymmetrical TTF-MnMo6-SP POMs using the $\mathrm{H}_{2} \mathrm{~N}-\mathrm{MnMo}_{6}-\mathrm{NH}_{2}$ and $\mathrm{H}_{2} \mathrm{~N}-\mathrm{MnMo}_{6}-\mathrm{SP}$ precursors, respectively. This latter complex was synthesized by reaction of the $\mathrm{H}_{2} \mathrm{~N}-\mathrm{MnMo}_{6}-\mathrm{NH}_{2}$ platform with 0.6 equivalent of $\mathrm{SPCO}_{2} \mathrm{H}$, as previously described. ${ }^{16}$ It can be noted that such monofunctionalization of the MnMo6 Anderson POM using a low carboxylic acid derivative/POM ratio has only been rarely possible, hence the choice of the AlMo6 $\mathrm{POM}$ precursor for the synthesis of an Anderson POM functionalized by a single TTF molecule. The hybrid compounds were characterized by a series of complementary techniques. Elemental analysis, ${ }^{1} \mathrm{H}$ and ${ }^{13} \mathrm{C} \mathrm{NMR}$, confirm the presence of the organic molecules and both the TBA/SP and TBA/TTF ratios. For the unsymmetrical TTF- 
MnMo6-SP, the signals related to the protons belonging to the TTF or SP group can be clearly distinguished in the ${ }^{1} \mathrm{H}$ NMR spectrum evidencing the expected SP/TTF ratio of 1/1 (Figures S1). In addition, the presence of two signals at 172.2 and $168.1 \mathrm{ppm}$ in its ${ }^{13} \mathrm{C}$ NMR spectrum denotes the grafting onto the inorganic platform of the two distinct entities (SP and TTF respectively) via amide functions. FT-IR spectra show the $\mathrm{Mo}=\mathrm{O}$ vibrations of the polyoxomolybdate core around $900 \mathrm{~cm}^{-1}$ and the presence of a $\mathrm{C}=\mathrm{O}$ stretching band characteristic of a-(O)C-NH- linkage, at 1655, 1675 and $1677 \mathrm{~cm}^{-1}$ for TTF-AlMo6, TTFMnMo6-TTF and TTF-MnMo6-SP, respectively. ESI/MS spectra were also recorded for the three hybrids (Figure $\mathrm{S} 2$ ). The $[\mathrm{M}+2 \mathrm{TBA}]^{-}$(M referring to the trianionic moiety) peak is clearly observed for each compound, confirming the covalent linkage between the POM and the organic moiety.

Single crystals of TTF-MnMo6-TTF were obtained by slow diffusion of $\mathrm{Et}_{2} \mathrm{O}$ in an acetonitrile solution of the hybrid POM. TTF-MnMo6-TTF crystallizes in the rhombohedral $R-3$ space group. There are two independent complexes in the asymmetric unit. In one of the complex (with space occupancy factor 1/3), the TTF and the MnMo6 fragments are disordered and surrounded by disordered TBA cations, this disorder being induced by the presence of the -3 symmetry axis. The structure of the non-disordered anion (with space occupancy factor 1) is shown in Figure 3a. It confirms that TTF-MnMo6-TTF is built of a $\mathrm{MnMo}_{6}$ Anderson-type core with two TTF molecules symmetrically grafted via an amide function. The TTF fragment is slightly more distorted than in the $(\mathrm{MeS})_{3} \mathrm{TTF}\left(\mathrm{S}-\mathrm{CH}_{2}-\mathrm{CO}_{2} \mathrm{H}\right)$ precursor (Table S2). Furthermore, the central $\mathrm{C}=\mathrm{C}$ distance is close to that observed in the neutral precursor which indicates that the TTF fragment is non oxidized in the hybrid complex. The TTF moieties of one complex interact via intermolecular $S^{\cdots} \mathrm{S}$ and $\pi-\pi$ interactions with that of neighboring complexes thus forming infinite chains (Figures $3 b$ and 3c). 


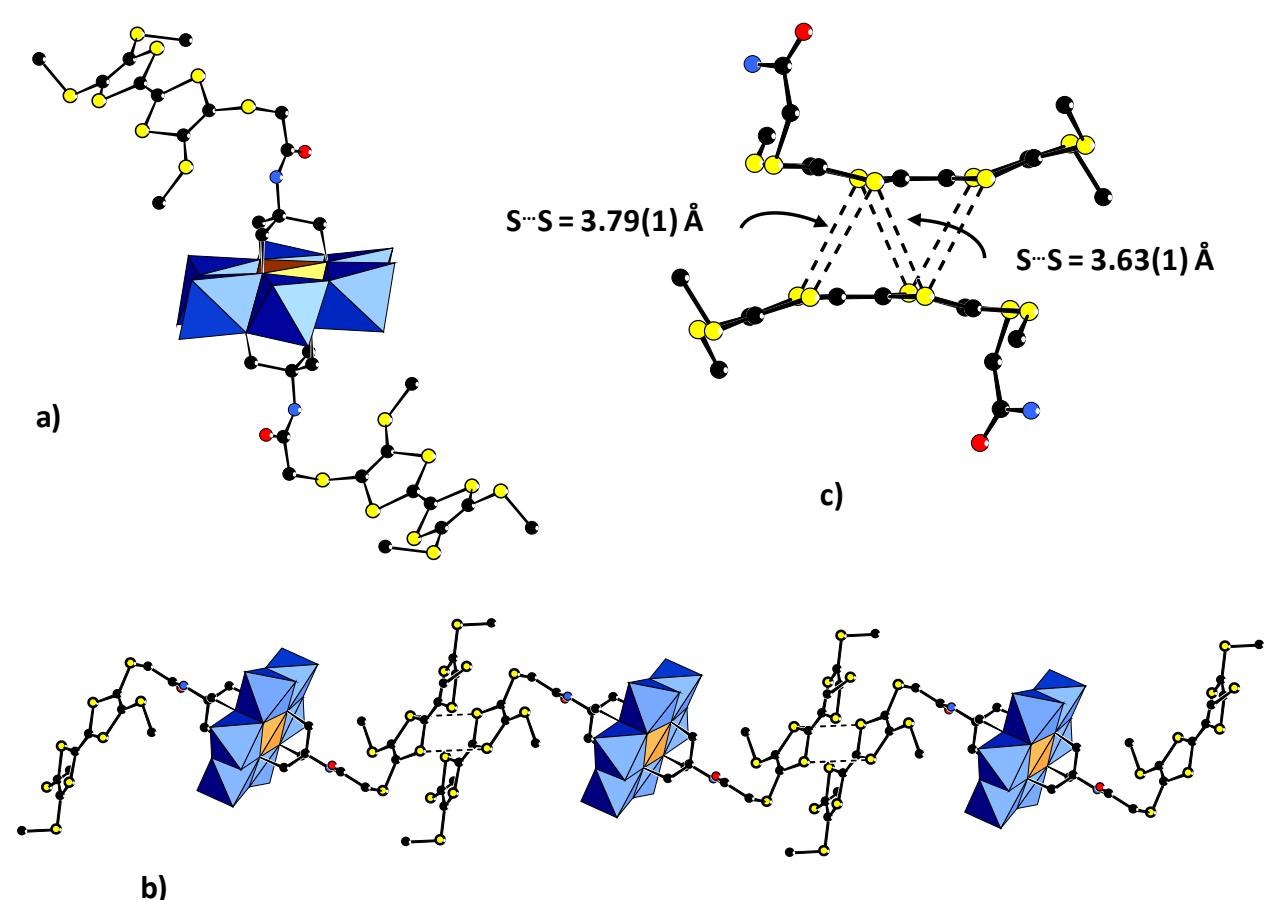

b)

Figure 3. Structure of TTF-MnMo6-TTF; a) view of the molecular structure, b) chain formed by supramolecular interactions between the molecules, c) side view of the TTF moieties in interaction within the chain; black spheres $=\mathrm{C}$, red spheres $=\mathrm{O}$, yellow spheres $=\mathrm{S}$, blue spheres $=\mathrm{N}$, blue octahedra $=\mathrm{MoO}_{6}$, orange octahedra $=\mathrm{MnO}_{6}$; hydrogen atoms have been omitted for clarity.

Electrochemical and Spectroelectrochemical Properties. The electrochemical behaviors of the three complexes TTF-AIMo6, TTF-MnMo6-SP and TTF-MnMo6-TTF have been studied by cyclic voltammetry and compared to their precursors $(\mathrm{MeS})_{3} \mathrm{TTF}\left(\mathrm{S}-\mathrm{CH}_{2}-\right.$ $\left.\mathrm{CO}_{2} \mathrm{H}\right), \mathrm{H}_{2} \mathrm{~N}-\mathrm{MnMo}_{6}-\mathrm{NH}_{2}$ and $\mathrm{H}_{2} \mathrm{~N}-\mathrm{MnMo}_{6}-\mathrm{SP}$ studied in similar conditions. Cyclic voltammograms (Figure 4 and Figures S3-S9), peak potentials and the separation between the anodic and the cathodic peaks of the redox processes $\Delta \mathrm{E}_{\mathrm{p}}$ are gathered in Table 1. Plots of the peak current $\mathrm{I}_{\mathrm{pc}} v s$. the square root of the scan rate $\mathrm{v}^{1 / 2}$ for the reversible processes are also given in Figures S3-S9.

As known for TTF derivatives, for $(\mathrm{MeS})_{3} \mathrm{TTF}\left(\mathrm{S}-\mathrm{CH}_{2}-\mathrm{CO}_{2} \mathrm{H}\right)$ two well-defined reversible and monoelectronic oxidation waves are observed at 0.587 and $0.928 \mathrm{~V}$ vs. SCE (Figure 4). The first one corresponds to the oxidation of the neutral species forming the stable 
radical monocation $\mathrm{TTF}^{+\bullet}$ and the second one to the formation of the dication $\mathrm{TTF}^{2+}$. The cyclovoltammogram of TTF-AlMor exhibits also the two successive oxidation waves attributed to the transformation of the neutral TTF unit into the dication through the stable monocation redox state of the TTF subunit (Figure 4). However, due to adsorption phenomena on the glassy carbon electrode the reversibility of the second oxidation process is not well defined. Furthermore, the oxidation of the TTF unit is sensitive to the electron donating (or withdrawing) properties of substituents. Here, compared to the TTF precursor, the presence of the AlMo6 Anderson type POM connected to the TTF unit induces a cathodic shift of the oxidation potentials by $187 \mathrm{mV}$ and $158 \mathrm{mV}$ at 0.400 and $0.770 \mathrm{~V}$ respectively. This is in agreement with the high electron density of the Anderson type polyoxometalate which has a 3charge compared to the neutral carboxylic acid. In addition, the shift may also be tentatively explained by the formation of an ion pair between the POM and the oxidized TTF. 

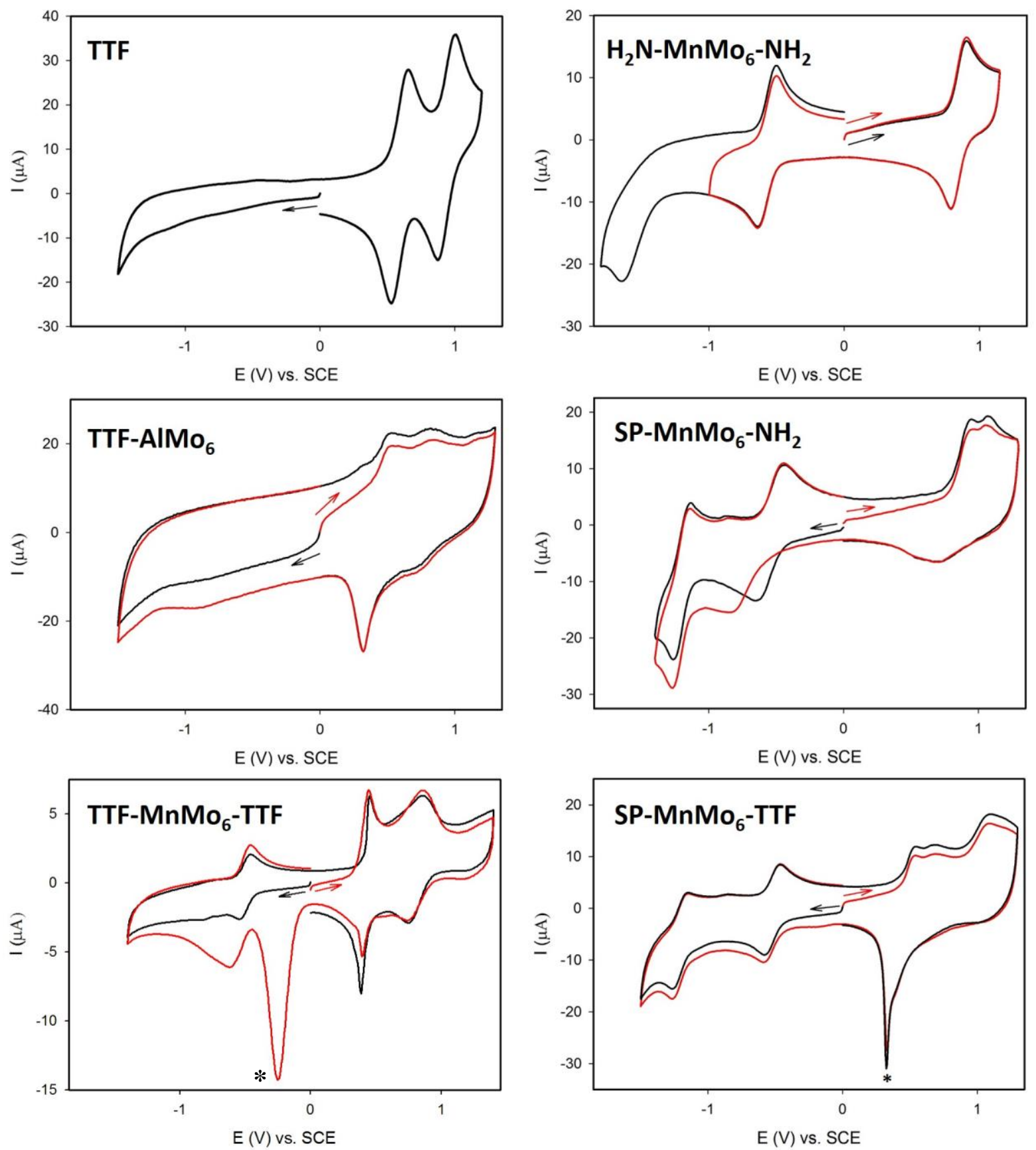

Figure 4. Cyclic voltammograms of $(\mathrm{MeS})_{3} \mathrm{TTF}\left(\mathrm{S}-\mathrm{CH}_{2}-\mathrm{CO}_{2} \mathrm{H}\right)$, TTF-AIMo6, TTF-MnMo6TTF, $\mathrm{H}_{2} \mathrm{~N}-\mathrm{MnMo}_{6}-\mathrm{NH}_{2}, \mathrm{H}_{2} \mathrm{~N}-\mathrm{MnMo}_{6}-\mathrm{SP}$ and TTF-MnMo6-SP at a glassy carbon electrode $(\mathrm{d}=3 \mathrm{~mm}) v s . \mathrm{SCE}$ in 1,2-EtCl 2 with $0.1 \mathrm{M} \mathrm{TBAPF}_{6}$ as the supporting electrolyte. Scan rate: $100 \mathrm{mVs}^{-1}$. $\left(^{*}\right)$ cathodic redissolution peak due to the adsorption of the oxidized species on the electrode.

In the case of $\mathrm{H}_{2} \mathrm{~N}-\mathrm{MnMo}_{6}-\mathrm{NH}_{2}$, one reversible oxidation wave is observed at $0.846 \mathrm{~V}$ and attributed to the $\mathrm{Mn}^{\mathrm{IV} / \mathrm{III}}$ couple. In the cathodic domain, two successive reductions at 
-0.574 and $-1.641 \mathrm{~V}$ have been measured (Figure 4), corresponding to the reduction of the central $\mathrm{Mn}$ ion $\left(\mathrm{Mn}^{\mathrm{III} / \mathrm{II}}\right.$ couple) and the first irreversible reduction of the Mo ions $\left(\mathrm{Mo}^{\mathrm{VI} / \mathrm{V}}\right.$ couple) of the POM unit respectively. $\mathrm{H}_{2} \mathrm{~N}-\mathrm{MnMo}_{6}-\mathrm{SP}$ shows an electrochemical behaviour close to that of $\mathrm{H}_{2} \mathrm{~N}-\mathrm{MnMo}_{6}-\mathrm{NH}_{2}$, but with the presence of one additional peak at $1.061 \mathrm{~V}$, ascribed to the irreversible oxidation of the SP unit. ${ }^{16}$ The oxidation of the central Mn ion of the POM unit is observed at $0.831 \mathrm{~V}$ and is easier by $15 \mathrm{mV}$ in comparison with $\mathrm{H}_{2} \mathrm{~N}-\mathrm{MnMo}_{6}$ $\mathrm{NH}_{2}$. The reversible reduction waves at -0.541 and $-1.330 \mathrm{~V}$ attributed to the reduction of the $\mathrm{Mn}\left(\mathrm{Mn}^{\mathrm{III} / \mathrm{II}}\right.$ couple $)$ and $\mathrm{Mo}\left(\mathrm{Mo}^{\mathrm{VI} / \mathrm{V}}\right.$ couple $)$ centers of the POM unit respectively are shifted towards less cathodic potentials (33 $\mathrm{mV}$ and $311 \mathrm{mV}$ respectively).

The electrochemical patterns of TTF-MnMo6-SP consist of three oxidative processes at $0.435,0.700$ and $1.080 \mathrm{~V}$ (Figure 4). The first oxidation is assigned to the monoelectronic TTF unit oxidation giving the radical monocation $\mathrm{TTF}^{+}$, while the second oxidation is irreversible and corresponds to the overlap of the second oxidation of the TTF unit as well as the oxidation of the Mn ion of the POM unit. The third oxidation process is ascribed to the irreversible oxidation of the SP unit already observed for $\mathrm{H}_{2} \mathrm{~N}-\mathrm{MnMo}_{6}-\mathrm{SP}$. It must be noted that on the reverse sweep, a large spike at around $+0.3 \mathrm{~V}$ is observed and corresponds to the cathodic redissolution peak. The phenomenon is due to the strong adsorption of the oxidized species on the electrode. On the cathodic scan, two reversible reduction waves at -0.525 and $-1.215 \mathrm{~V}$ are detected and can be attributed to the reduction of the Mn and Mo centers respectively as observed for $\mathrm{H}_{2} \mathrm{~N}-\mathrm{MnMo}_{6}-\mathrm{NH}_{2}$ and $\mathrm{H}_{2} \mathrm{~N}-\mathrm{MnMo}_{6}-\mathrm{SP}$.

TTF-MnMo6-TTF exhibits two oxidation waves at 0.415 and $0.798 \mathrm{~V}$ (Figure 4 and Figure S8). The first oxidation process corresponds to the oxidation of the two TTF units into the radical cations $\mathrm{TTF}^{+\bullet}$. The second oxidation wave is attributed to the overlap of the two radical cation $\mathrm{TTF}^{+}$units into the two $\mathrm{TTF}^{2+}$ as well as the monoelectronic oxidation of the central $\mathrm{Mn}$ ion $\left(\mathrm{Mn}^{\mathrm{IV} / I I I}\right.$ couple) of the POM unit. One important desorption peak at $-0.24 \mathrm{~V}$ is 
detected but only after the scan in oxidation (red curve, Figure 4) showing important adsorption after the oxidation of the TTF units on the glassy carbon electrode. As already observed for TTF-MnMo6-SP and TTF-AIMo6, the oxidation of the TTF unit is easier by $172 \mathrm{mV}$ compared to the TTF precursor, $(\mathrm{MeS})_{3} \mathrm{TTF}\left(\mathrm{S}-\mathrm{CH}_{2}-\mathrm{CO}_{2} \mathrm{H}\right)$. Additionally, one reversible reduction attributed to the $\mathrm{Mn}^{\mathrm{III} / \mathrm{II}}$ couple at $-0.505 \mathrm{~V}$ is detected.

Table 1. Electrochemical data for $(\mathrm{MeS})_{3} \mathrm{TTF}\left(\mathrm{S}-\mathrm{CH}_{2}-\mathrm{CO}_{2} \mathrm{H}\right)$, TTF-AlMo6, $\mathrm{H}_{2} \mathrm{~N}-\mathrm{MnMo}_{6}-\mathrm{NH}_{2}$, $\mathrm{H}_{2} \mathrm{~N}-\mathrm{MnMo}_{6}-\mathrm{SP}$, TTF-MnMo6-TTF and TTF-MnMo6-SP.

\begin{tabular}{|c|c|c|c|c|c|}
\hline Compounds & SP & $\begin{array}{c}\mathrm{Mn}^{\mathrm{IV} / I I I} \\
\text { and/or TTF }\end{array}$ & TTF & $\mathrm{Mn}^{\mathrm{III} / \mathrm{II}}$ & $\mathrm{Mo}^{\mathrm{VI} / \mathrm{V}}$ \\
\hline$(\mathrm{MeS})_{3} \mathrm{TTF}\left(\mathrm{S}-\mathrm{CH}_{2}-\mathrm{CO}_{2} \mathrm{H}\right)^{\mathbf{a}}$ & & $0.928(115)$ & $0.587(105)$ & & \\
\hline TTF-AIMo6 $^{\text {a }}$ & & $0.770(100)$ & $0.400(200)$ & & b \\
\hline $\mathrm{H}_{2} \mathrm{~N}-\mathrm{MnMo}_{6}-\mathrm{NH}_{2}{ }^{\mathrm{a}}$ & & $0.846(113)$ & & $-0.574(128)$ & $-1.641^{\mathrm{irr}}$ \\
\hline $\mathrm{H}_{2} \mathrm{~N}-\mathrm{MnMo}_{6}-\mathrm{SP}^{\mathrm{a}}$ & $1.061 \mathrm{irr}$ & $0.831(222)$ & & $-0.541(114)$ & $-1.330(133)$ \\
\hline TTF-MnMo6-SP ${ }^{\text {a }}$ & $1.080^{\mathrm{irr}}$ & $0.700^{\mathrm{irr}}$ & $0.435(210)$ & $-0.525(68)$ & $-1.215(109)$ \\
\hline TTF-MnMo6-TTF a & & $0.798(96)$ & $0.415(63)$ & $-0.505(77)$ & $\mathrm{b}$ \\
\hline
\end{tabular}

${ }^{\text {a }}$ Potentials in $\mathrm{V}$ vs. SCE were obtained from cyclic voltammetry in $1,2-\mathrm{C}_{2} \mathrm{H}_{4} \mathrm{Cl}_{2}$ with $0.1 \mathrm{~mol} \mathrm{~L}^{-1} \mathrm{TBAPF}_{6}$. Scan rate $=100 \mathrm{mV} \mathrm{s}^{-1}$. Working electrode: $\mathrm{GC}, \mathrm{d}=3 \mathrm{~mm}$. The given half-wave potentials are equal to $\mathrm{E}_{1 / 2}=\left(\mathrm{E}_{\mathrm{pa}}+\right.$ $\left.\mathrm{E}_{\mathrm{pc}}\right) / 2$. Under bracket: $\triangle \mathrm{E}_{\mathrm{p}}=\left|\mathrm{E}_{\mathrm{pa}}-\mathrm{E}_{\mathrm{pc}}\right|$.

${ }^{\mathrm{b}}$ not measured

Solution spectroelectrochemical studies were carried out to obtain information about the electronic properties of all the compounds (Figure 5 and Figures S10-S14). The electrochemical oxidation of $(\mathrm{MeS})_{3} \mathrm{TTF}\left(\mathrm{S}-\mathrm{CH}_{2}-\mathrm{CO}_{2} \mathrm{H}\right)$ (Figures 5A and 5B) induces strong changes in the UV-Vis-NIR absorption spectra. In the neutral state, four absorbance bands are detected at 310, 331, 390, and $477 \mathrm{~nm}$ (weak). The two lower energy transitions are in good agreement with those reported for TTF compounds. These represent the transitions from the $\operatorname{HOMO}(\pi)$ to the $\operatorname{LUMO}\left(\sigma^{*}\right)$ and from the $\mathrm{HOMO}$ to $\mathrm{LUMO}+1 \pi \rightarrow \pi *$ respectively. ${ }^{32}$ 

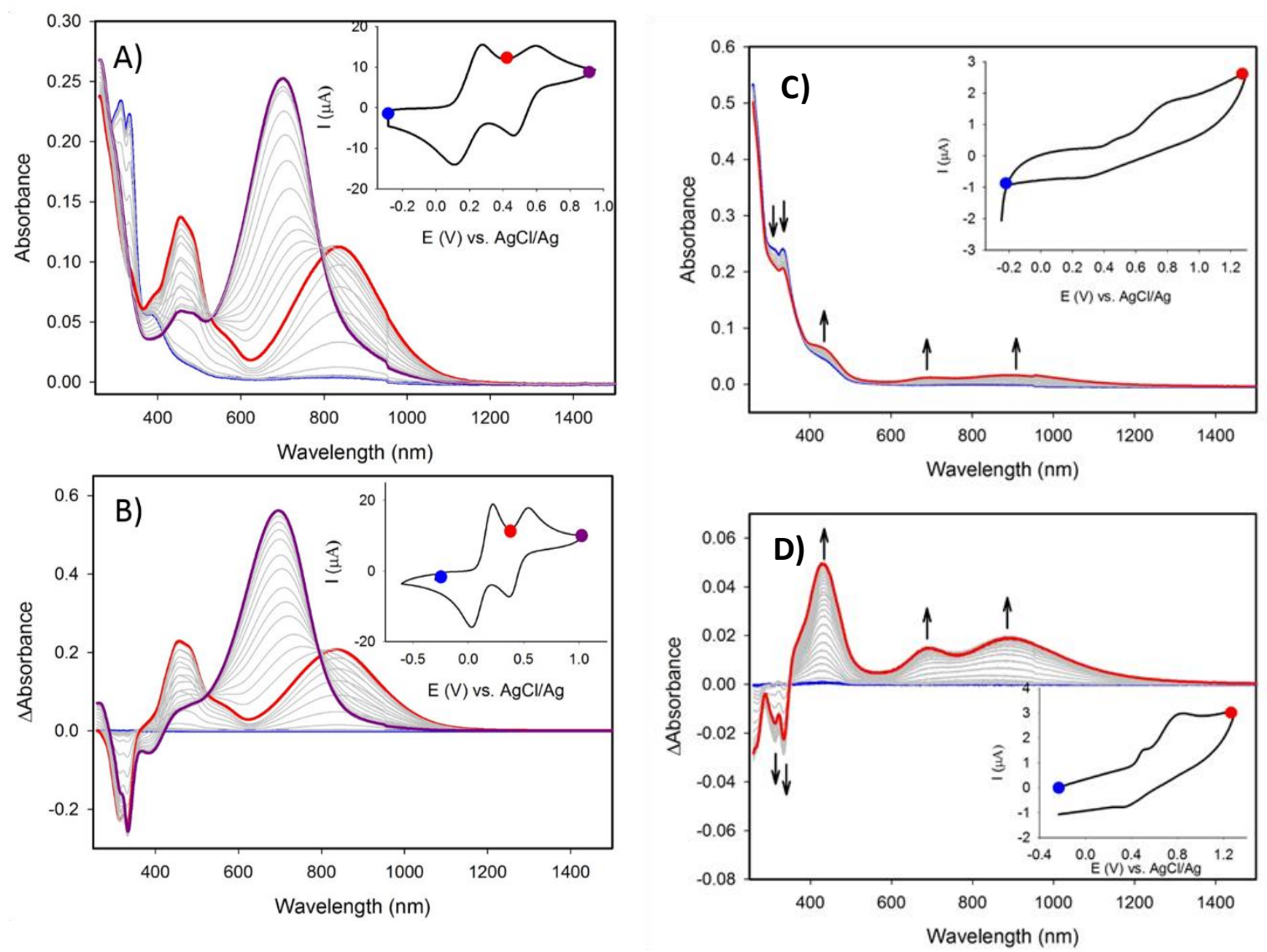

Figure 5. UV-Vis-NIR spectroelectrochemical study of $(\mathrm{MeS})_{3} \mathrm{TTF}\left(\mathrm{S}-\mathrm{CH}_{2}-\mathrm{CO}_{2} \mathrm{H}\right)$ and TTFMnMo6-SP at ambient temperature upon electrochemical oxidation in $1,2-\mathrm{EtCl}_{2}$ with $0.1 \mathrm{M}$ $\mathrm{TBAPF}_{6}$ as the supporting electrolyte. A) UV-Vis-NIR spectra recorded during the two successive oxidation of the TTF moiety of $(\mathrm{MeS})_{3} \mathrm{TTF}\left(\mathrm{S}-\mathrm{CH}_{2}-\mathrm{CO}_{2} \mathrm{H}\right)$ giving $\mathrm{TTF}^{+\bullet}$ and the dication $\mathrm{TTF}^{2+}$. B) Differential UV-Vis-NIR spectra recorded during the first and the second oxidation of $(\mathrm{MeS})_{3} \mathrm{TTF}\left(\mathrm{S}-\mathrm{CH}_{2}-\mathrm{CO}_{2} \mathrm{H}\right)$ respectively. C) UV-Vis-NIR spectra recorded during the successive oxidation of TTF-MnMo6-SP. D) Differential UV-Vis-NIR spectra recorded during the oxidation of TTF-MnMo6-SP. Inset shows the corresponding CV at a scan rate of 0.02 V.s. ${ }^{-1}$.

Upon oxidation to the cation radical state $\mathrm{TTF}^{+\bullet}$, a decrease in the absorbance bands at 310 and $331 \mathrm{~nm}$ is observed with the appearance and concomitant increase of new absorbance bands at 453, 480, 562 and $840 \mathrm{~nm}$ (red curve of Figures 5A and 5B). ${ }^{33} \mathrm{An}$ isosbestic point is found at $365 \mathrm{~nm}$ (Figures 5A and S10) indicating that conversion from $\mathrm{TTF}$ to $\mathrm{TTF}^{+\bullet}$ is a direct reaction with no side products or intermediates produced. Upon gradual oxidation to the dicationic species, $\mathrm{TTF}^{2+}$, a new absorption band centered at $702 \mathrm{~nm}$ grows together with the disappearance of the absorption band at $840 \mathrm{~nm}$ concomitantly with the decrease of the bands at 453 and $480 \mathrm{~nm}$ (Figure 5A). The UV-Vis-NIR absorption spectrum of the $\mathrm{TTF}^{2+}$ is shown in Figure 5 (purple curve). Differential UV-Vis-NIR spectra recorded during the first and the second oxidation of $(\mathrm{MeS})_{3} \mathrm{TTF}\left(\mathrm{S}-\mathrm{CH}_{2}-\mathrm{CO}_{2} \mathrm{H}\right)$ respectively give similar results (Figure $\left.5 \mathrm{~B}\right)$. It 
can be noted that the cyclic voltammograms, measured using a Pt grid working electrode during the spectroelectrochemical measurements, indicate that the two redox processes are reversible. The resulting absorption spectrum from reduction of the dicationic species back to the cation radical one as well as the reduction of the cation radical back to the neutral TTF supports this assumption with nearly a whole reversibility detected on the timescale of the spectroelectrochemical experiment (around $250 \mathrm{~s}$ in the case of Fig 5B). The change of the absorbance at 702 and $840 \mathrm{~nm}$ during the conversion of TTF to $\mathrm{TTF}^{+\bullet}$ and the further oxidation of $\mathrm{TTF}^{+\bullet}$ to $\mathrm{TTF}^{2+}$ (as well as the reduction of $\mathrm{TTF}^{2+}$ to $\mathrm{TTF}^{+\bullet}$ and then the reduction of $\mathrm{TTF}^{+}$. to TTF) are reported in Figure S10C showing that the radical monocation as well as the dication species are stable.

UV-Vis-NIR spectroelectrochemical experiments were also performed with the TTF derivatives. TTF-MnMo6-SP exhibits a behaviour similar to that of $(\mathrm{MeS})_{3} \mathrm{TTF}\left(\mathrm{S}-\mathrm{CH}_{2}-\right.$ $\left.\mathrm{CO}_{2} \mathrm{H}\right)$. Upon oxidation to the cation radical state of the TTF, $\mathbf{T T F}^{+\bullet}-\mathbf{M n M o 6}-\mathbf{S P}$, the decrease of the two bands at 311 and $332 \mathrm{~nm}$ occurs together with the increase of two bands at 431, and $894 \mathrm{~nm}$. When the potential reaches the second oxidation of the TTF unit, one additional band typical of the $\mathrm{TTF}^{2+}$ unit appears at $689 \mathrm{~nm}$ but without the disappearance of the two bands at 431 and $894 \mathrm{~nm}$ attributed to the $\mathrm{TTF}^{+\bullet}$ radical cation. This can be interpreted by the incomplete oxidation of the $\mathrm{TTF}^{+\bullet}$ unit possibly due to the irreversible wave detected on the Pt working electrode (Figures 5C and 5D) and/or adsorption phenomena. This irreversibility was also detected with glassy carbon electrode (Figure 4). It is impossible at the back sweep to regenerate the starting TTF-MnMo6-SP compound. This may be due to the irreversible oxidation of the spiro subunit which can induce radical coupling to form a dimer. ${ }^{34}$ The results of the spectroelectrochemical experiments on the other POMs are given in the SI section.

\section{NLO Properties}


HRS measurements were performed on the three novel TTF derivatives as well as on the TTF and SP precursors for comparison purposes (Table 2). The compounds were dissolved either in $\mathrm{CH}_{3} \mathrm{CN}$ or in $\mathrm{CH}_{2} \mathrm{Cl}_{2}$, depending on their solubility in each solvent. The comparison of the values obtained for $\mathrm{SPCO}_{2} \mathrm{H}$ in both solvents indicates that the solvent has little influence.

Table 2. HRS data at $1064 \mathrm{~nm}$ for the hybrid POM/TTF compounds compared to the organic precursor molecules. The $\beta$ values reported here are defined as $\sqrt{\left\langle\beta^{2}\right\rangle},\left\langle\beta^{2}\right\rangle$ being the orientational average value of the $\beta \otimes \beta 6^{\text {th }}$-rank tensor directly inferred from HRS measurements. ${ }^{44}$

\begin{tabular}{lll}
\hline Compound & Solvent / concentration & $\begin{array}{l}\boldsymbol{\beta}\left(\mathbf{1 0}^{-30} \mathbf{e s u}\right) \\
\text { (dynamic, @ 1.06 } \boldsymbol{\mu m})\end{array}$ \\
\hline $\mathrm{SPCO}_{2} \mathrm{H}$ & $\mathrm{CH}_{2} \mathrm{Cl}_{2} / 5 \times 10^{-3} \mathrm{M}$ & 9 \\
$\mathrm{SPCO}_{2} \mathrm{H}$ & $\mathrm{CH}_{3} \mathrm{CN} / 5 \times 10^{-3} \mathrm{M}$ & 9 \\
$(\mathrm{MeS})_{3} \mathrm{TTF}\left(\mathrm{S}-\mathrm{CH}_{2}-\mathrm{CO}_{2} \mathrm{H}\right)$ & $\mathrm{CH}_{3} \mathrm{CN} / 2.5 \times 10^{-3} \mathrm{M}$ & 11 \\
TTF-AIMo6 & $\mathrm{CH}_{3} \mathrm{CN} / 10^{-3} \mathrm{M}$ & 30 \\
TTF-AIMo6 +1 eq. $\mathrm{Fe}^{3+}$ & $\mathrm{CH}_{3} \mathrm{CN} / 10^{-3} \mathrm{M}$ & 40 \\
TTF-MnMo6-SP & $\mathrm{CH}_{3} \mathrm{CN} / 10^{-3} \mathrm{M}$ & 20 \\
TTF-MnMo6-SP +1 eq Fe $\mathrm{Fe}^{3+}$ & $\mathrm{CH}_{3} \mathrm{CN} / 10^{-3} \mathrm{M}$ & 41 \\
TTF-MnMo6-TTF & $\mathrm{CH}_{2} \mathrm{Cl} / 10^{-3} \mathrm{M}$ & 37
\end{tabular}

These measurements show a clear effect of the grafting of the TTF unit on the MnMo6 Anderson core on the $\beta$ values, which increase from around 10 for the organic molecular precursors to 20-40 for the hybrid compounds. These values are in the order of magnitude of that found for the well-known 4-dimethylamino-N-methyl-4-stilbazolium $\left(\mathrm{DAS}^{+}\right)$cation (dynamic orientational average value $\beta=60 \times 10^{-30}$ esu measured also by HRS $)^{35}$ but are lower than that observed for organo-imido Lindqvist derivatives with grafted donor organic molecules7 due probably to the lack of conjugation between the POM and the TTF moieties. 
The high value observed for the centrosymmetric TTF-MnMo6-TTF complex is remarkable. This indicates that in solution, the TTF groups do not necessarily adopt a fully "trans" conformation with respect to the central MnMo6 platform (Figure S16). Due to the flexibility of the covalent linkage between TTF and the central unit, some "cis-like" conformation may appear in solution, resulting in a centrosymmetry breaking and a related emergence of a significant $\beta$ value of the molecule. In fact, if we do not consider TTF-MnMo6-TTF as a single molecule, but as an ensemble of $N=2(\mathrm{MeS})_{3} \mathrm{TTF}\left(\mathrm{S}-\mathrm{CH}_{2}-\mathrm{CO}_{2} \mathrm{H}\right)$ molecular units, the expected $\beta$ value of this ensemble (without considering the role of POM for the moment) would be $\beta_{\text {ensemble }}=\sqrt{N} \beta_{\text {unit }}$, resulting in $\beta_{\text {ensemble }}=16.10^{-30}$ esu. This value being much lower than the experimental one $\left(37.10^{-30} \mathrm{esu}\right)$ for TTF-MnMo6-TTF, the role of POM in the increase of $\beta$ values of hybrid POM/TTFs as compared to that of their TTF counterparts is clearly confirmed. If we compare now the $\beta$ value of TTF-MnMo6-TTF to that of an ensemble of two TTFAlMo6 molecules, we find from $\beta_{\text {ensemble }}=\sqrt{N} \beta_{\text {unit }}$ that $\beta_{\text {ensemble }}=42.10^{-30}$ esu, a value closer to that of TTF-MnMo6-TTF. This comparison is of course a rough estimate, as the TTFAlMo6 "monomer" is not exactly the same as TTF-MnMo6; moreover, the central POM unit is counted twice in the calculation of $\beta_{\text {ensemble. Anyway, these consideration confirm the essential }}$ role of the POM in the strong enhancement of the $\beta$ value of TTF derivatives, which cannot be explained by the replacement of the $\mathrm{COOH}$ moiety by the amide group (this latter one being slightly less electro-attractive than $\mathrm{COOH})$ when attaching $(\mathrm{MeS})_{3} \mathrm{TTF}\left(\mathrm{S}-\mathrm{CH}_{2}-\mathrm{CO}_{2} \mathrm{H}\right)$ to $\mathrm{POM}$ units.

Considering the exact origin of the important POM contribution to the NLO properties of TTF/POM hybrids, we propose that the POM shows a significant electro-attractive effect enhancing the electronic properties of the amide group, even if the POM and the TTF derivative are not conjugated, rather than an addition of the intrinsic $\beta$ value of the TTF unit to that of the 
POM. Indeed this later value is expected to be very weak because of the centrosymmetric character of the POM moiety.

We have also studied the effect of TTF oxidation on the NLO properties of the two TTF hybrids TTF-AIMo6 and TTF-MnMo6-SP. The oxidation was performed by addition of 1 eq. of $\mathrm{FeCl}_{3}$, following a reported procedure. ${ }^{36}$ These measurements could not be performed on TTFMnMo6-TTF because of the formation of a precipitate after addition of $\mathrm{Fe}^{3+}$. After addition of 1 eq. of $\mathrm{Fe}^{3+}$ the solution of SP-MnMo6-TTF changed from pink to brown and the solution of TTF-AIMor from orange to green. A change of the UV-Vis spectra of the solutions was concomitantly observed (Figure S15). These spectra present similarities with the spectra recorded during the spectroelectrochemical measurements (Figures $5 \mathrm{C}$ and $\mathrm{S} 12 \mathrm{~A}$ ), in particular the decrease of the bands at 311 and $333 \mathrm{~nm}$ together with the appearance of a large band around $800 \mathrm{~nm}$. Furthermore the appearance of a green color is typical of the formation of $\mathrm{TTF}^{+\bullet}$ radicals. These results confirm the oxidation of the TTF moieties within the hybrids. It can be observed that the oxidation of the TTF fragment increases the $\beta$ values of the compounds (Table 2). In spite of the fact that oxidization of TTF might reduce its electron-donor character, the creation of the radical induces new absorption bands in the visible and near-IR (see Figure 5A) which significantly enhances the $\beta$ values of the molecule according to the resonance model proposed by Oudar and Chemla: ${ }^{37}$

$$
\beta=\frac{3 e^{2} h^{2}}{8 \pi^{2} m} \frac{W \cdot f . \Delta \mu_{E x}}{\left(W^{2}-2 h \omega^{2}\right)\left(W^{2}-h \omega^{2}\right)}
$$

where h $\omega$ is the energy of the laser photon at $1.06 \mu \mathrm{m}, \mathrm{W}$ and $f$ are the energy and oscillator strength of the corresponding excited state, and $\Delta \mu_{\mathrm{Ex}}$ is the difference between excited state and ground state dipole moments.

In particular, the band appearing at $536 \mathrm{~nm}$ for TTF-AIMo6 comes very close to the second harmonic wavelength at $532 \mathrm{~nm}$. However, the very weak intensity of this band might be related 
to a low oscillator strength, then keeping the contribution of this resonance to the $\beta$ value at a modest level. Therefore, the relative increase of $\beta$ for this molecule upon single oxidation is only $30 \%$. On the contrary, the intensity of the new absorption bands induced by the single oxidation of TTF-MnMo6-SP is significantly higher, with a higher oscillator strength, resulting in a higher increase of the $\beta$ value (by a factor of 2 ).

\section{Conclusions}

While several ionic assemblies of POMs and TTF molecules have been reported in the literature, TTF-AIMo6, TTF-MnMo6-TTF and TTF-MnMo6-SP represent the first examples of hybrid complexes where a TTF molecule is covalently grafted on a POM. Electrochemical experiments show that the redox signals attributed to the inorganic and organic counterparts are influenced by their covalent attachment. Furthermore, these molecules represent rare examples of polyoxometalates exhibiting second order non linear optical properties. Further studies will explore the synthesis of crystalline molecular materials by oxidation of the TTF molecules in order to see the influence of the POM on the crystal packing and the conducting properties.

\section{EXPERIMENTAL SECTION}

The

$$
(\mathrm{MeS})_{3} \mathrm{TTF}\left(\mathrm{S}-\mathrm{CH}_{2}-\mathrm{CO}_{2} \mathrm{H}\right)^{26}
$$

and

POM

precursors

$(\mathrm{TBA})_{3}\left[\mathrm{AlMo}_{6} \mathrm{O}_{18}(\mathrm{OH})_{3}\left\{\left(\mathrm{OCH}_{2}\right)_{3} \mathrm{CNH}_{2}\right\}\right]$

$\left((\mathrm{TBA})_{3} \mathrm{H}_{2} \mathrm{~N}-\mathrm{AlMo} 6\right),{ }^{31}$

(TBA) $)_{3}\left[\mathrm{MnMo}_{6} \mathrm{O}_{18}\left\{\left(\mathrm{OCH}_{2}\right)_{3} \mathrm{CNH}_{2}\right\}_{2}\right]$

$\left((\mathrm{TBA})_{3} \mathrm{H}_{2} \mathrm{~N}-\mathrm{MnMo}_{6}-\mathrm{NH}_{2}\right)^{38}$

and

$(\mathrm{TBA})_{3}\left[\mathrm{MnMo}_{6} \mathrm{O}_{18}\left\{\left(\mathrm{OCH}_{2}\right)_{3} \mathrm{CNH}_{2}\right\}\left\{\left(\mathrm{OCH}_{2}\right)_{3} \mathrm{CNHC}_{21} \mathrm{H}_{19} \mathrm{~N}_{2} \mathrm{O}_{4}\right] \quad\left((\mathrm{TBA})_{3} \mathrm{H}_{2} \mathrm{~N}-\mathrm{MnMo}_{6}-\mathrm{SP}\right)^{16}\right.$ 
were synthesized according to reported procedures. 2-Ethoxy-1-ethoxycarbonyl-1,2dihydroquinoline (EEDQ) was purchased from Alfa Aesar and was used as received.

\section{Experimental Procedures and Characterization Data.}

Synthesis of (TBA) $)_{3}\left[\mathrm{AlMo6}_{18}(\mathrm{OH})_{3}\left\{\left(\mathrm{OCH}_{2}\right)_{3} \mathrm{CNHC}_{11} \mathrm{H}_{11} \mathrm{~S}_{8} \mathrm{O}\right\}\right]$ ((TBA) $\left.)_{3} \mathrm{TTF}-\mathrm{AlMo6}\right): \mathrm{A}$ solution of $(\mathrm{TBA})_{3} \mathrm{H}_{2} \mathrm{~N}-\mathrm{AlMo}_{6}(0.250 \mathrm{~g}, 0.131 \mathrm{mmol}),(\mathrm{MeS})_{3} \mathrm{TTF}\left(\mathrm{S}-\mathrm{CH}_{2}-\mathrm{CO}_{2} \mathrm{H}\right)(0.113 \mathrm{~g}$, $0.260 \mathrm{mmol})$ and EEDQ $(0.074 \mathrm{~g}, 0.300 \mathrm{mmol})$ in acetonitrile $(10 \mathrm{~mL})$ was stirred at $50^{\circ} \mathrm{C}$ for 3 days. After cooling to room temperature, the orange solution was filtered and the filtrate concentrated. The remaining solution was added to a large amount of diethyl ether and the resulting precipitate was isolated by filtration under vacuum. This treatment was repeated three times. (TBA) $)_{3}$ TTF-AlMo6 $(0.240 \mathrm{~g}, 0.106 \mathrm{mmol})$ was isolated as an orange powder in $81 \%$ yield. ${ }^{1} \mathrm{H}$ NMR (CD 3 CN, $\left.300 \mathrm{MHz}, 298 \mathrm{~K}\right) \delta 6.19$ (br., $1 \mathrm{H},-\mathrm{NH}-$ ), 4.77 (s, 6H, -C-CH $-\mathrm{C}$ ), 4.22 (br, 3H, -OH), 3.32 (s, 2H, -S-CH $), 3.16$ (m, 24H, $\left.-\mathrm{NCH}_{2} \mathrm{CH}_{2}-(\mathrm{TBA})\right), 2.56$ (s, 3H, -S-CH 3 ), 2.44 (s, 3H, -S-CH 3$), 2.43$ (s, 3H, -S-CH 3 ), 1.65 (m, 24H, - $\mathrm{NCH}_{2} \mathrm{CH}_{2^{-}}$(TBA)), 1.39 (st, 24H, $\left.\mathrm{NCH}_{2} \mathrm{CH}_{2} \mathrm{CH}_{2} \mathrm{CH}_{3}, \mathrm{~J}=6 \mathrm{~Hz}(\mathrm{TBA})\right), 0.99\left(\mathrm{t}, 36 \mathrm{H},-\mathrm{CH}_{3}, \mathrm{~J}=6 \mathrm{~Hz}(\mathrm{TBA})\right) .{ }^{13} \mathrm{C} \mathrm{NMR}\left(\mathrm{CD}_{3} \mathrm{CN}\right.$, $75 \mathrm{MHz}, 298 \mathrm{~K}) \delta 167.6\left(\mathrm{C}_{\mathrm{TTF}}\right), 128.6\left(\mathrm{C}_{\mathrm{TTF}}\right), 127.8\left(\mathrm{C}_{\mathrm{TTF}}\right), 111.5\left(\mathrm{C}_{\mathrm{TTF}}\right), 110.7\left(\mathrm{C}_{\mathrm{TTF}}\right), 75.4$ $\left(\mathrm{C}_{\mathrm{TTF}}\right), 59.2\left(\mathrm{C}_{\mathrm{TBA}}\right), 40.6\left(\mathrm{C}_{\mathrm{TTF}}\right), 24.4\left(\mathrm{C}_{\mathrm{TBA}}\right), 20.3\left(\mathrm{C}_{\mathrm{TBA}}\right), 19.6\left(\mathrm{C}_{\mathrm{TTF}}\right), 19.4\left(\mathrm{C}_{\mathrm{TTF}}\right), 13.9\left(\mathrm{C}_{\mathrm{TBA}}\right)$. ${ }^{27} \mathrm{Al}$ NMR $\left(\mathrm{CD}_{3} \mathrm{CN}, 298 \mathrm{~K}\right) \delta$ 16.92. IR (ATR) : v $\left(\mathrm{cm}^{-1}\right) 3281(\mathrm{w}), 2957$ (vC-H, m), $2930(v \mathrm{C}-$ H, m), 2871 (vC-H, m), $1655(\mathrm{vC}=\mathrm{O}, \mathrm{s}), 1561(\mathrm{~m}), 1480(\mathrm{~s}), 1434(\mathrm{~m}), 1382(\mathrm{~s}), 1328(\mathrm{~m})$, $1254(\mathrm{w}), 1215(\mathrm{w}), 1152(\mathrm{w}), 1124(\mathrm{w}), 1100(\mathrm{w}), 1064(\mathrm{~m}), 1046(\mathrm{~m}), 938$ (vMo=O, vs), 917 (vMo=O, vs), $900(v \mathrm{Mo}=\mathrm{O}, \mathrm{vs}), 833(\mathrm{w}), 772(\mathrm{w}), 736(\mathrm{w}), 646$ (vMo-O-Mo, vs, br.), 575 (s), 509 (m). Anal. Calcd for $\mathrm{AlMo}_{6} \mathrm{O}_{25} \mathrm{C}_{63} \mathrm{H}_{129} \mathrm{~N}_{4} \mathrm{~S}_{8}$ (2201.97): C, $34.33 ; \mathrm{H}, 5.86 ; \mathrm{N}, 2.54 ; \mathrm{S}$, 11.65. Found : C, $35.22 ; \mathrm{H}, 6.29 ; \mathrm{N}, 2.52 ; \mathrm{S}, 10.43$.

Synthesis of (TBA) $)_{3}\left[\mathrm{MnMo6}_{18}\left\{\left(\mathrm{OCH}_{2}\right)_{3} \mathrm{CNHC}_{11} \mathrm{H}_{11} \mathrm{~S}_{8} \mathrm{O}\right\}_{2}\right]$ ((TBA) $\left.)_{3} \mathrm{TTF}-\mathrm{MnMo6}-\mathrm{TTF}\right)$ : A suspension of $(\mathrm{MeS})_{3} \mathrm{TTF}\left(\mathrm{S}-\mathrm{CH}_{2}-\mathrm{CO}_{2} \mathrm{H}\right)(0.276 \mathrm{~g}, 0.638 \mathrm{mmol})$ and EEDQ $(0.174 \mathrm{~g}, 0.704$ mmol) in acetonitrile $(15 \mathrm{~mL})$ was stirred under reflux for 1 hour. (TBA) ${ }_{3} \mathrm{H}_{2} \mathrm{~N}-\mathrm{MnMo}_{6}-\mathrm{NH}_{2}$ 
( $0.300 \mathrm{~g}, 0.159 \mathrm{mmol})$ was then added to the solution and the reflux maintained for 5 days. After cooling to room temperature, the dark solution was concentrated and then added to a large amount of diethyl ether. The resulting precipitate was isolated by filtration under vacuum. This treatment was repeated three times. (TBA) ${ }_{3}$ TTF-MnMo6-TTF $(0.270 \mathrm{~g}, 0.100 \mathrm{mmol})$ was isolated as a pale brown powder in $63 \%$ yield. ${ }^{1} \mathrm{H}$ NMR $\left(\mathrm{CD}_{3} \mathrm{CN}, 300 \mathrm{MHz}, 298 \mathrm{~K}\right) \delta 65.03(\mathrm{~s}$, br., $\left.12 \mathrm{H},-\mathrm{CH}_{2}-\mathrm{O}\right), 6.98$ (br., $\left.2 \mathrm{H},-\mathrm{NH}-\right), 3.61$ (s, 4H, S-CH$\left.-\mathrm{C}\right), 3.11$ (m, 24H, $-\mathrm{NCH}_{2}-\mathrm{CH}_{2}$ (TBA)), 2.54 (s, 6H, -S-CH 3$), 2.44\left(\mathrm{~s}, 12 \mathrm{H},-\mathrm{S}_{-} \mathrm{CH}_{3}\right), 1.61\left(\mathrm{~m}, 24 \mathrm{H},-\mathrm{NCH}_{2} \mathrm{CH}_{2^{-}}\right.$(TBA)), 1.37 (m, 24H, $-\mathrm{NCH}_{2} \mathrm{CH}_{2} \mathrm{CH}_{2-}$ (TBA)), 0.99 (m, 36H, - $\mathrm{CH}_{3}$ (TBA)). ${ }^{13} \mathrm{C}$ NMR (DMSO, $75 \mathrm{MHz}$, $298 \mathrm{~K}) \delta 168.9\left(\mathrm{C}_{\mathrm{TTF}}\right), 132.0\left(\mathrm{C}_{\mathrm{TTF}}\right), 126.8$ (С $\left.\mathrm{C}_{\mathrm{TTF}}\right), 126.0\left(\mathrm{C}_{\mathrm{TTF}}\right), 122.7\left(\mathrm{C}_{\mathrm{TTF}}\right), 110.7\left(\mathrm{C}_{\mathrm{TTF}}\right)$, $109.9\left(\mathrm{C}_{\mathrm{TTF}}\right), 57.5$ (С $\left.\mathrm{C}_{\mathrm{TBA}}\right), 30.7$ (С $\left(\mathrm{C}_{\mathrm{TTF}}\right), 13.5\left(\mathrm{C}_{\mathrm{TBA}}\right)$. IR (ATR) : v $\left(\mathrm{cm}^{-1}\right) 3325(\mathrm{w}), 2957$ (vC-H, m), $2930(v \mathrm{C}-\mathrm{H}, \mathrm{m}), 2870(v \mathrm{C}-$ H, m), $1675(v C=O, s), 1518(\mathrm{~m}), 1480(\mathrm{~s}), 1426(\mathrm{~m}), 1378(\mathrm{~m}), 1312(\mathrm{~m}), 1254(\mathrm{w}), 1150(\mathrm{w})$, $1116(\mathrm{w}), 1066(\mathrm{~m}), 1029(\mathrm{~s}), 938(\mathrm{vMo}=\mathrm{O}, \mathrm{vs}), 919(\mathrm{vMo}=\mathrm{O}, \mathrm{vs}), 901(\mathrm{vMo}=\mathrm{O}, \mathrm{vs}), 877(\mathrm{~s})$, 773 (w), 737 (w), 651 (vMo-O-Mo, vs, br.), 562 (s), 515 (s). Anal. Calcd for $\mathrm{MnMo}_{6} \mathrm{O}_{26} \mathrm{C}_{78} \mathrm{H}_{144} \mathrm{~N}_{5} \mathrm{~S}_{16.2} \mathrm{CH}_{3} \mathrm{CN}(2793.84): \mathrm{C}, 35.22 ; \mathrm{H}, 5.37 ; \mathrm{N}, 3.51 ; \mathrm{S}, 18.36$. Found : C, $34.46 ; \mathrm{H}, 5.44 ; \mathrm{N}, 3.71 ; \mathrm{S}, 18.60$.

Synthesis of $(\mathrm{TBA})_{3}\left[\mathrm{MnMo6}_{18}\left\{\left(\mathrm{OCH}_{2}\right)_{3} \mathrm{CNHC}_{20} \mathrm{H}_{29} \mathrm{~S}_{8} \mathrm{O}\right\}\left\{\left(\mathrm{OCH}_{2}\right)_{3} \mathrm{CNHC}_{21} \mathrm{H}_{19} \mathrm{~N}_{2} \mathrm{O}_{4}\right\}\right]$ ((TBA) $)_{3}$ SP-MnMo6-TTF): A suspension of $(\mathrm{MeS})_{3} \mathrm{TTF}\left(\mathrm{S}-\mathrm{CH}_{2}-\mathrm{CO}_{2} \mathrm{H}\right)(0.058 \mathrm{~g}, 0.134 \mathrm{mmol})$, $(\mathrm{TBA})_{3} \mathrm{H}_{2} \mathrm{~N}-\mathrm{MnMo}_{6}-\mathrm{SP}(0.100 \mathrm{~g}, 0.045 \mathrm{mmol})$ and EEDQ $(0.036 \mathrm{~g}, 0.146 \mathrm{mmol})$ in acetonitrile $(5 \mathrm{~mL})$ was stirred at room temperature for one week. The solution was then concentrated and added to a large amount of diethyl ether $(40 \mathrm{~mL})$. The resulting precipitate was isolated by filtration under vacuum. This treatment was repeated three times. (TBA) ${ }_{3} \mathbf{S P}$ MnMo6-TTF (0.073 g, $0.027 \mathrm{mmol})$ was isolated as a pink solid in $60 \%$ yield. ${ }^{1} \mathrm{H}$ NMR $\left(\mathrm{CD}_{3} \mathrm{CN}, 300 \mathrm{MHz}, 298 \mathrm{~K}\right) \delta 64.85$ (s, br., 12H, - $\left.\mathrm{CH}_{2}-\mathrm{O}\right), 8.06$ (s, 1H, HsP), 8.00 (d, 1H, HsP), $7.15\left(\mathrm{~m}, 3 \mathrm{H}, \mathrm{H}_{\mathrm{SP}}\right), 6.85$ (t, 1H, $\left.\mathrm{H}_{\mathrm{SP}}\right), 6.71$ (m, 2H, $\left.\mathrm{H}_{\mathrm{SP}}\right), 6.45$ (br., 2H, -NH-), 5.90 (d, 1H, $\left.\mathrm{H}_{\mathrm{SP}}\right)$, 
3.63 (s, 2H, HTTF, S-CH $\left.{ }_{2}-\mathrm{C}\right), 3.51\left(\mathrm{~m}, 1 \mathrm{H}, \mathrm{H}_{\mathrm{SP}}\right), 3.36\left(\mathrm{~m}, 1 \mathrm{H}, \mathrm{H}_{\mathrm{SP}}\right), 3.13\left(\mathrm{~m}, 24 \mathrm{H},-\mathrm{NCH}_{2}-\right.$ (TBA)), 2.71 (m, 2H, $\mathrm{H}_{\mathrm{SP}}$ ), 2.54 (s, 3H, $\left.\mathrm{H}_{\mathrm{TTF}},-\mathrm{S}-\mathrm{CH}_{3}\right), 2.45$ (s, 3H, $\left.\mathrm{H}_{\mathrm{TTF}},-\mathrm{S}-\mathrm{CH}_{3}\right), 2.44$ (s, 3H, HTTF, $\left.-\mathrm{S}-\mathrm{CH}_{3}\right), 1.63$ (m, 24H, - $\mathrm{NCH}_{2} \mathrm{CH}_{2}$ ( $\left.\mathrm{TBA}\right)$ ), 1.39 (m, 24H, - $\left.\mathrm{NCH}_{2} \mathrm{CH}_{2} \mathrm{CH}_{2}-(\mathrm{TBA})\right), 1.24$ (s, 3H, HSP), 1.13 (s, 3H, HsP), 0.98 (m, 36H, - $\left.\mathrm{CH}_{3}(\mathrm{TBA})\right) .{ }^{13} \mathrm{C} \mathrm{NMR}\left(\mathrm{CD}_{3} \mathrm{CN}, 75 \mathrm{MHz}, 298 \mathrm{~K}\right)$ $\delta 172.3\left(\mathrm{C}_{\mathrm{SP}}\right), 168.1\left(\mathrm{C}_{\mathrm{TTF}}\right), 159.4\left(\mathrm{C}_{\mathrm{SP}}\right), 146.7\left(\mathrm{C}_{\mathrm{SP}}\right), 141.1\left(\mathrm{C}_{\mathrm{SP}}\right), 136.1\left(\mathrm{C}_{\mathrm{SP}}\right), 134.3\left(\mathrm{C}_{\mathrm{TTF}}\right)$, $128.9\left(\mathrm{C}_{\mathrm{SP}}\right), 127.8\left(\mathrm{C}_{\mathrm{SP}}\right), 127.7\left(\mathrm{C}_{\mathrm{TTF}}\right), 126.9\left(\mathrm{C}_{\mathrm{TTF}}\right), 125.6\left(\mathrm{C}_{\mathrm{SP}}\right), 123.5\left(\mathrm{C}_{\mathrm{SP}}\right), 122.9\left(\mathrm{C}_{\mathrm{SP}}\right), 121.7$ $\left(\mathrm{C}_{\mathrm{SP}}\right), 120.9\left(\mathrm{C}_{\mathrm{TTF}}\right), 119.4\left(\mathrm{C}_{\mathrm{SP}}\right), 119.1\left(\mathrm{C}_{\mathrm{SP}}\right), 115.4\left(\mathrm{C}_{\mathrm{SP}}\right), 110.7\left(\mathrm{C}_{\mathrm{TTF}}\right), 109.8\left(\mathrm{C}_{\mathrm{TTF}}\right), 107.2$ (C $\left.\mathrm{C}_{\mathrm{SP}}\right), 107.1\left(\mathrm{CSP}_{\mathrm{SP}}\right), 58.4\left(\mathrm{C}_{\mathrm{TBA}}\right), 52.6\left(\mathrm{C}_{\mathrm{SP}}\right), 40.7\left(\mathrm{C}_{\mathrm{SP}}\right), 38.0\left(\mathrm{C}_{\mathrm{TTF}}\right), 33.8\left(\mathrm{C}_{\mathrm{SP}}\right), 26.1\left(\mathrm{C}_{\mathrm{SP}}\right), 23.5$ (C $\left.\mathrm{C}_{\mathrm{TBA}}\right), 22.5\left(\mathrm{C}_{\mathrm{TTF}}\right), 19.7\left(\mathrm{C}_{\mathrm{TBA}}\right), 19.1$ (C $\left.\mathrm{C}_{\mathrm{SP}}\right), 18.5$ (C $v\left(\mathrm{~cm}^{-1}\right) 3314(\mathrm{w}), 2959$ (vC-H, m), 2931 (vC-H, m), 2871 (vC-H, m), $1677(v \mathrm{C}=\mathrm{O}, \mathrm{s}), 1553$ (w), $1515(\mathrm{~m}), 1480$ (s), $1458(\mathrm{~s}), 1379(\mathrm{w}), 1333$ (s), $1274(\mathrm{~m}), 1157(\mathrm{w}), 1109(\mathrm{~m}), 1087(\mathrm{~m})$, $1024(\mathrm{~s}), 939(v \mathrm{Mo}=\mathrm{O}, \mathrm{vs}), 918(\mathrm{vMo}=\mathrm{O}, \mathrm{vs}), 900(v \mathrm{Mo}=\mathrm{O}, \mathrm{vs}), 807(\mathrm{w}), 746(\mathrm{~s}), 654$ (vMoO-Mo, vs, br.), 562 (s), 518 (s). Anal. Calcd for $\mathrm{MnMo}_{6} \mathrm{O}_{29} \mathrm{C}_{88} \mathrm{H}_{152} \mathrm{~N}_{7} \mathrm{~S}_{8}$ (2659.40): C, 39.71; H, 5.72; N, 3.69; S, 9.65. Found: C, 39.36; H, 5.82; N, 3.60; S, 9.05.

Infrared spectra were recorded on a Nicolet 30 ATR 6700 FT spectrometer. EDX measurements were performed on a JEOL JSM 5800LV apparatus. ${ }^{1} \mathrm{H}$ NMR spectra were recorded at $298 \mathrm{~K}$ on a Bruker Advance 300 spectrometer operating at $300 \mathrm{MHz}$. Elemental analyses were performed by the Service de Microanalyse of CNRS, 91198 Gif-sur-Yvette, France.

Electrospray ionization (ESI) mass spectra were recorded on a Xevo QTof WATERS (quadrupole-time-of-flight) instrument. The temperature of the source block was set to $120^{\circ} \mathrm{C}$, and the desolvation temperature to $380{ }^{\circ} \mathrm{C}$. A capillary voltage of $2.5 \mathrm{kV}$ was used in the negative scan mode, and the cone voltage was set to $30 \mathrm{~V}$ to control the extent of fragmentation of the identified species. Mass calibration was performed using a solution of sodium formate in 
water:acetonitrile (2:8) from m/z 50 to 1500 . Sample solutions were injected via syringe pump directly connected to the ESI source at a flow rate of $10 \mu \mathrm{L} / \mathrm{min}$.

Electrochemical and Spectroelectrochemical measurements. Voltammetric data were recorded with a standard three-electrode system using a PARSTAT 2273 potentiostat. The electrolyte was $1,2-\mathrm{C}_{2} \mathrm{H}_{4} \mathrm{Cl}_{2}$ containing $0.1 \quad \mathrm{~mol} \quad \mathrm{~L}^{-1} \quad$ of tetrabutylammoniumhexafluorophosphate $\left(\mathrm{NBu}_{4} \mathrm{PF}_{6}\right)$. Glassy carbon electrode $(\mathrm{d}=3 \mathrm{~mm})$ was used as working electrode, and a platinum wire as auxiliary electrode. The reference electrode was the saturated calomel electrode that was electrically connected to the solution by a junction bridge filled with electrolyte.

UV-Vis-NIR spectroelectrochemical experiments were performed with an optically transparent thin-layer electrochemical (OTTLE) cell (University of Reading UK, Hartl, F.) equipped with a Pt grid working electrode and $\mathrm{CaF}_{2}$ optical windows. ${ }^{39} \mathrm{UV}-\mathrm{Vis}-\mathrm{NIR}$ spectroelectrochemical analyses were carried out with a Zeiss MCS 601 UV-Vis-NIR diode array spectrometer. Spectrophotometric analyses of the films were conducted using a $0.1 \mathrm{M}$ solution of $\mathrm{Bu}_{4} \mathrm{NPF}_{6}$ in 1,2- $\mathrm{C}_{2} \mathrm{H}_{4} \mathrm{Cl}_{2}$. The concentration of hybrid POMs in the solution was $1 \mathrm{mM}$. The OTTLE cell consists of a demountable cell body equipped with a set of $\mathrm{CaF}_{2}$ optical windows $(41 \times 23 \times 6$ $\mathrm{mm}$ ) allowing to perform UV-vis-NIR-IR spectroelectrochemical experiments. The windows are separated with a modified polyethylene spacer (thickness of ca $0.2 \mathrm{~mm}=$ optical path) with a melt-sealed three-electrode system consisting of a Pt minigrid working electrodes (32 wires/cm), a Pt minigrid auxiliary electrode and an Ag wire pseudoreference electrode. The wire contacts are stable against air oxidation and shielded from electronic noise. Results are reported in Figures S9-S13.

Crystal Structure Determination. Single crystal X-ray diffraction data collection were carried out by using an APEXII Bruker-AXS $\left((\mathrm{MeS})_{3} \mathrm{TTF}\left(\mathrm{S}-\mathrm{CH}_{2}-\mathrm{CO}_{2} \mathrm{H}\right)\right)$ and a Bruker Nonius X8 APEX 2 (TTF-MnMo6-TTF), each equipped with a CCD bidimensional detector using the 
monochromatised wavelength $\lambda(\mathrm{Mo} \mathrm{K} \alpha)=0.71073 \AA$. Absorption corrections were based on multiple and symmetry-equivalent reflections in the data set using the SADABS program ${ }^{40}$ based on the method of Blessing. ${ }^{41}$ The structure was solved by direct methods and refined by full-matrix least-squares using the SHELX-TL package. ${ }^{42}$ The data set of TTF-MnMo6-TTF was corrected with the program SQUEEZE, ${ }^{43}$ a part of the PLATON package of crystallographic software used to calculate the solvent or counter-ion disorder area and to remove its contribution to the overall intensity data. The $\mathrm{R}$ values are quite high for this structure. Despite several attempts (use of other solvents, concentrations, temperatures), it was not possible to get crystals of better quality. Crystallographic data are given in Table S1 and the complete data can be found in the cif file as Supporting Information.

NLO measurements. Harmonic light scattering was performed at $1.064 \mu \mathrm{m}$ from a Q- switched $\mathrm{Nd}^{3+}$ : YAG nanosecond laser (SAGA from Thales Laser) at a $10 \mathrm{~Hz}$ repetition rate. The detected signal is then sampled, averaged processed by a computer. A low intensity reference beam is extracted from the main beam at a $45^{\circ}$ incidence angle by a glass plate and focused onto a highly nonlinear NPP (N-4-nitrophenyl-prolinol) powder used as a frequency doubler. The variation of the second harmonic intensity scattered from the solution is recorded on the computer as a function of the reference second harmonic signal provided by the NPP powder, both signals scaling as the square of the incoming fundamental intensity $\mathrm{I}_{\omega}$.

The scattered harmonic signal $\mathrm{I}^{2 \omega}$ from a solution is given by:

$$
I^{2 \omega}=g\left(N_{S}\left\langle\beta_{S}^{2}\right\rangle+N\left\langle\beta^{2}\right\rangle\right) I_{\omega}^{2}
$$

where $\mathrm{g}$ is a geometry factor, $\mathrm{N}_{\mathrm{S}}$ and $\mathrm{N}$ are the number of solvent molecules and nanoparticles per unit volume respectively; $\beta_{\mathrm{S}}$ and $\beta$ are the molecular hyperpolarizability of the solvent and nonlinear molecule, respectively. From the slopes $\mathrm{P}$ (respectively $\mathrm{P}_{0}$ ) of the lines obtained for the solution (respectively solvent) by recording the variation of $\mathrm{I}^{2 \omega}$ as a function of $I_{N N P}^{2 \omega}$ (the 
SHG intensity from a reference NLO material (NPP) sample which is proportional to $I_{\omega}^{2}$ ), we can infer the $\beta$ values of the molecules of interest. ${ }^{44}$

\section{ASSOCIATED CONTENT}

Supporting Information. This material is available free of charge via the Internet at http://pubs.acs.org.

\section{AUTHOR INFORMATION}

Corresponding Authors. $\underline{\text { ruhlmann@unistra.fr, anne.dolbecq@uvsq.fr }}$

\section{ACKNOWLEDGMENT}

This work was supported by CNRS, UVSQ, Université de Rennes 1, ENS Paris Saclay and the French ANR (grant ANR-11-BS07-011-01-BIOOPOM). We also thank the Université de Strasbourg and the Labex "Chimie des Systèmes Complexes" (CSC) of the University of Strasbourg for financial support. This work was also supported by the China Scholarship Council (CSC) for the PhD grant of Z.H.

\section{REFERENCES}




\section{Table of Content Graphic}

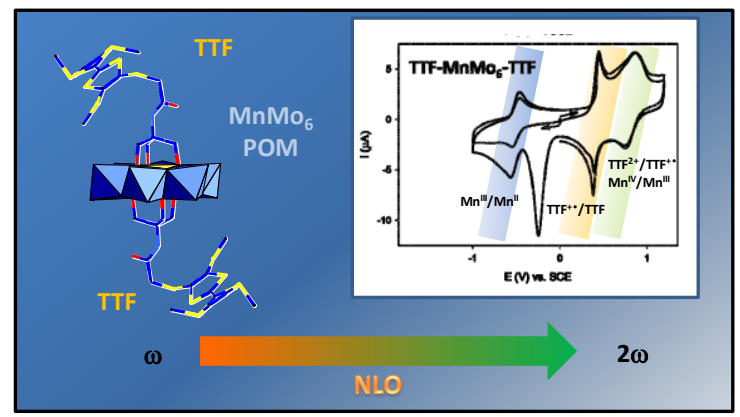

Three Anderson-type polyoxometalates (POMs) functionalized by tetrathiafulvalene (TTF) molecules have been synthesized and studied by electrochemistry, UV-vis-NIR spectroelectrochemistry and Hyper-Rayleigh Scattering (HRS).

${ }^{1}$ Pope, M. T.; Müller, A. Polyoxometalate Chemistry : An Old Field with New Dimensions in Several Disciplines. Angew. Chem. Int. Ed. 1991, 30, 34.

${ }^{2}$ Special issue on Polyoxometalates, Chem. Rev. 1998, 98, 1-390.

3 (a) Proust, A.; Matt, B.; Villanneau, R.; Guillemot, G.; Gouzerh, P.; Izzet, G. Functionalization and Post-Functionalization : a Step Towards Polyoxometalate-Based Materials. Chem. Soc. Rev. 2012, 41, 7605. (b) Song, Y.-F.; Tsunashima, R. Recent Advances on PolyoxometalateBased Molecular and Composite Materials. Chem. Soc. Rev. 2012, 41, 7384. (c) Santoni, M.P.; Hanan, G. S.; Hasenknopf, B. Covalent Multi-Component Systems of Polyoxometalates and Metal Complexes: Toward Multi-Functional Organic-Inorganic Hybrids in Molecular and Materials Sciences. Coord. Chem. Rev. 2014, 281, 64. (d) Genovese, M.; Lian, K. Polyoxometalate Modified Inorganic-Organic Nanocomposite Materials for Energy Storage Applications: A Review. Current Opinion in Solid State and Materials Science 2015, 19, 126. (e) Herrmann, S.; Ritchie, C.; Streb, C. Polyoxometalate-conductive Polymer Composite for 
Energy Conversion, Energy Storage and Nanostructured Sensors. Dalton Trans. 2015, 44, 7092.

${ }^{4}$ Matt, B.; Fize, J.; Moussa, J.; Amouri, H.; Pereira, A.; Artero, V.; Izzet, G.; Proust, A. Charge Photo-Accumulation And Photocatalytic Hydrogen Evolution under Visible Light at an Iridium(III)-Photosensitized Polyoxotungstate. Energy Environ. Sci. 2013, 6, 1504.

${ }^{5}$ (a) Saad, A.; Zhu, W.; Rousseau, G.; Mialane, P.; Marrot, J.; Haouas, M.; Taulelle, F.; Dessapt, R.; Serier-Brault, H.; Rivière, E.; Kubo, T.; Oldfield, E.; Dolbecq, A. Polyoxomolybdate Bisphosphonate Heterometallic Complexes: Synthesis, Structure, and Activity on a Breast Cancer Cell Line. Chem. Eur. J. 2015, 21, 10537. (b) Boulmier, A.; Feng, X.; Oms, O.; Mialane, P.; Rivière, E.; Shin, C. J.; Yao, J.; Kubo, T.; Furuta, T.; Oldfield, E.; Dolbecq, A. Anticancer Activity of Polyoxometalate-Bisphosphonate Complexes: Synthesis, Characterization, In Vitro and In Vivo Results. Inorg. Chem. 2017, 56, 7558.

${ }^{6}$ (a) Janjua, M. R. S. A.; Liu, C.-G.; Guan, W.; Zhuang, J.; Muhammad, S.; Yan, L.-K.; Su, Z.M. Prediction of Remarkably Large Second-Order Nonlinear Optical Properties of Organoimido-Substituted Hexamolybdates. J. Phys. Chem. A 2009, 113, 3576. (b) Liu, C.-G.; Guan, X.-H. Computational Study on Redox-Switchable Second-Order Nonlinear Optical Properties of Totally Inorganic Keggin-Type Polyoxometalate Complexes. J. Phys. Chem. C 2013, 117, 7776. (c) Zhang, T.; Ma, N.; Yan, L.; Ma, T. Su, Z. Theoretical Exploration on Switchable NLO Response Induced by Photochromic Properties of Covalently Connected Unsymmetrical Spiropyran-Polyoxometalate Complex. Dyes and Pigments 2014, 106, 105.

${ }^{7}$ (a) Al-Yasari, A.; Van Steerteghem, N.; El Moll, H.; Clays, K.; Fielden, J. Donor-Acceptor Organo-Imido Polyoxometalates: High Transparency, High Activity Redox-Active NLO Chromophores. Dalton Trans. 2016, 45, 2818. (b) Al-Yasari, A.; Van Steerteghem, N.; Kearns, H.; El Moll, H.; Faulds, K.; Wright, J. A.; Brunschwig, B. S.; Clays, K.; Fielden, J. 
Organoimido-Polyoxometalate Nonlinear Optical Chromophores: A Structural, Spectroscopic, and Computational Study. Inorg. Chem. 2017, 56, 10181.

${ }^{8}$ (a) Compain, J.-D.; Mialane, P.; Dolbecq, A.; Marrot, J.; Proust, A.; Nakatani, K.; Yu, P.; Sécheresse, F. Second-Order Nonlinear Optical Properties of Polyoxometalate Salts of a Chiral Stilbazolium Derivative. Inorg. Chem. 2009, 48, 6222. (b) Veltman, T. R.; Stover, A. K.; Sarjeant, A. N.; Ok, K. M.; Halasyamani, P. S.; Norquist, A. J. Directed Synthesis of Noncentrosymmetric Molybdates Using Composition Space Analysis. Inorg. Chem. 2006, 45, 5529. (c) Hou, Y.; An, H.; Xu, T.; Zhao, S.; Luo, J. Chiral Polyoxomolybdate-Based Hybrid Compounds Obtained by Spontaneous Resolution: Syntheses, Structures and Non-linear Optical Properties. New. J. Chem. 2016, 40, 10316. (d) Zhang, X.-M.; Shan, B.-Z.; Duan, C.Y.; You, X.-Z. Second-order Non-linear Optical Response of a Novel Type of Charge-transfer Complex, [4-DMSP $]_{4}\left[\mathrm{NH}_{2} \mathrm{Me}_{2}\right] \mathrm{HSiFeMo}{ }_{11} \mathrm{O}_{40} \cdot 3 \mathrm{H}_{2} \mathrm{O}$. Chem. Commun. 1997, 1131.

${ }^{9}$ Blazevic, A.; Rompel, A. The Anderson-Evans Polyoxometalate: From Inorganic Building Blocks via Hybrid Organic-Inorganic Structures to Tomorrows "Bio-POMs". Coord. Chem. Rev. 2016, 307, 42.

${ }^{10}$ (a) Allain, C.; Schaming, D.; Karakostas, N.; Erard, M.; Gisselbrecht, J.-P.; Sorgues, S.; Lampre, I.; Ruhlmann, L.; Hasenknopf, B. Synthesis, Electrochemical and Photophysical Properties of Covalently Linked Porphyrin-Polyoxometalates. Dalton Trans. 2013, 42, 2745. (b) Ban, Y.; Li, B.; He, Q.; He, Z.; Ai, H.; Wang, H.; Yin, Z.; Wu, L. Synthesis and RedoxResponsive Self-Assembly of Ferrocene Grafted Anderson-Type Polyoxometalate Hybrid Complexes. Soft Matter 2012, 8, 1593. (c) Li, X.-X.; Wang, Y.-X.; Wang, R.-H.; Cui, C.-Y; Tian, C.-B.; Yang, G.-Y. Designed Assembly of Heterometallic Cluster Organic Frameworks Based on Anderson-Type Polyoxometalate Clusters. Angew. Chem. Int. Ed. 2016, 55, 6462.

${ }^{11}$ (a) Yvon, C.; Macdonelle, A.; Buchwald, S.; Surman, A. J.; Follet, N.; Alex, J.; Long, D.-L.; Cronin, L. A Collection of Robust Methodologies for the Preparation of Asymmetric Hybrid 
Mn-Anderson Polyoxometalates for Multifunctional Materials. Chem. Sci. 2013, 4, 3810. (b)

Zhang, J.; Luo, J.; Wang, P.; Ding, B.; Huang, Y.; Zhao, Z.; Zhang, J.; Wei, Y. Step-by-Step

Strategy from Achiral Precursors to Polyoxometalate-Based Chiral Organic-Inorganic Hybrids. Inorg. Chem. 2015, 54, 2551. (c) Zhang, B.; Yue, L.; Wang, Y.; Yang, Y.; Wu, L. A Novel Single-Side Azobenzene-Grafted Anderson-Type Polyoxometalate for Recognition-Induced Chiral Migration. Chem. Commun. 2014, 50, 10823. (d) Xu, Q.; Yuan, S.; Zhu, L.; Hao, J.; Wei, Y. Synthesis of Novel Bis(Triol)-Functionalized Anderson Clusters Serving as Potential Synthons for Forming Organic-Inorganic Hybrid Chains. Chem. Commun. 2017, 53, 5283.

${ }^{12}$ Ji, Y.; Hu, J.; Huang, L.; Chen, W.; Streb, C.; Song, Y.-F. Covalent Attachment of AndersonType Polyoxometalates to Single-Walled Carbon Nanotubes Gives Enhanced Performance Electrodes for Lithium Ion Batteries. Chem. Eur. J. 2015, 21, 6469.

13 (a) Schönweiz, S.; Heiland, M.; Anjass, M.; Jacob, T.; Rau, S.; Streb, C. Experimental and Theoritical Investigation of the Light-Driven Hydrogen Evolution by PolyoxometalatePhotosensitizer Dyads. Chem. Eur. J. 2017, 23, 15370. (b) Schönweiz, S.; Rommel, S. A.; Kübel, J.; Micheel, M.; Dietzek, B.; Rau, S.; Streb, C. Covalent photosensitizerpolyoxometalate catalyst dyads for visible light-driven hydrogen evolution. Chem. Eur. J. 2016, $22,12002$.

${ }^{14}$ Yang, H.-K.; Cheng, Y.-X.; Su, M.-M. ; Xiao, Y. ; Hu, M.-B.; Wang, W. PolyoxometalateBiomolecule Conjugates : a New Approach to Create Hybrid Drugs for Cancer Therapeutics. Bioorg. Med. Chem. Lett. 2013, 23, 1462.

15 (a) Vanhaecht, S.; Jacobs, J.; Van Meervelt, L.; Parac-Vogt, T. A Versatile and Highly Efficient Post-Functionalization Method for Grafting Organic Molecules onto Anderson-Type Polyoxometalates. Dalton Trans. 2015, 44, 19059. (b) Wang, L.-S.; Lu, Y.; Ó Máille, G. M.; Anthony, S. P. ; Nolan, D. ; Draper, S. M. Sonogashira Cross-Coupling as a Route to Tunable Hybrid Organic-Inorganic Rods with a Polyoxometalate Backbone. Inorg. Chem. 2016, 55, 
9497. (c) Vanhaecht, S.; Quanten, T.; Parac-Vogt, T. N. A Simple Nucleophilic Substitution as a Versatile Postfunctionalization Method for the Coupling of Nucleophiles to an AndersonType Polyoxometalate. Inorg. Chem. 2017, 56, 3095.

${ }^{16}$ Oms, O.; Hakouk, K.; Dessapt, R.; Deniard, P.; Jobic, S.; Dolbecq, A.; Palacin, T.; Nadjo, L.; Keita, B.; Marrot, J.; Mialane, P. Photo- and Electrochromic Properties of Covalently Connected Symmetrical and Unsymmetrical Spiro-pyran-Polyoxometalate Dyads. Chem. Commun. 2012, 48, 12103.

${ }^{17}$ (a) Saad, A.; Oms, O.; Marrot, J.; Dolbecq, A.; Hakouk, K.; El Bekkachi, H.; Jobic, S.; Deniard, P.; Dessapt, R.; Garrot, D.; Boukheddaden, K.; Liu, R.; Zhang, G.; Keita, B.; Mialane, P. Design and Optical Investigations of a Spironaphtoxazine/Polyoxometalate/Spiropyran Triad. J. Mater. Chem. C 2014, 2, 4748. (b) Saad, A.; Oms, O.; Dolbecq, A.; Menet, C.; Dessapt, R.; Serier-Brault, H. ; Allard, E.; Baczko, K.; Mialane, P. A High Fatigue Resistant, Photoswitchable Fluorescent Spiropyran-Polyoxometalate-BODIPY Single-Molecule. Chem. Commun. 2015, 51, 16088. (c) Chu, Y.; Saad, A.; Yin, P.; Wu, J.; Oms, O.; Dolbecq, A.; Mialane, P.; Liu, T. Light and Solvent-Controlled Self-Assembly Behavior of SpiropyranPolyoxometalate-Alkyl Hybrid Molecules. Chem. Eur. J. 2016, 22, 11756.

18 (a) Bryce, M. R. Functionalised Tetrathiafulvalenes: New Applications as Versatile $\pi$ electron Systems in Materials Chemistry. J. Mater Chem. 2000, 10, 589. (b) Batail, P. (Ed.), Special issue on Molecular Conductors, Chem. Rev. 2004, 104, 4887. (c) Lorcy, D.; Bellec, N.; Fourmigué, M.; Avarvari, N. Tetrathiafulvalene-based Group XV Ligands: Synthesis, Coordination Chemistry and Radical Cation Salts. Coord. Chem. Rev. 2009, 253, 1398. (d) Pop, F.; Avarvari, N. Covalent Non-Fused Tetrathiafulvalene-Acceptor Systems. Chem. Commun. 2016, 52, 7906.

${ }^{19}$ González, M.; Segura, J. L.; Seoaane, C.; Martín, N.; Garín, J.; Orduna, J.; Alcalá, R.; Villacampa, B.; Hernández, V.; López Navarette, J. T. Tetrathiafulvalene Derivatives as NLO- 
phores: Synthesis, Electrochemistry, Raman Spectroscopy, Theoretical Calculations and NLO Properties of Novel TTF-Derived Donor- $\pi$-Acceptor Dyads. J. Org. Chem. 2001, 66, 8872.

${ }^{20}$ Coronado, E.; Giménez-Saiz, C.; Gómez-García, C. J. Recent Advances in Polyoxometalatecontaining Molecular Conductors. Coord. Chem. Rev. 2005, 249, 1776.

${ }^{21}$ Zhang, S.; Lu, X.; Sun, J.; Zhao, Y. ; Shao, X. Honeycomb Supramolecular Frameworks of Organic-inorganic Hybrid Cluster Composed of Cation Radical and Keggin-type Polyoxometalates. CrystEngComm 2015, 17, 4110.

${ }^{22}$ Tsunashima, R.; Iwamoto, Y.; Baba, Y.; Kato, C.; Ichihashi, K.; Nishihara, S.; Inoue, K.; Ishiguro, K.; Song, Y.-F.; Akutagawa, T. Electrical Network of Single-Crystalline Metal Oxide Nanoclusters Wired by $\pi$-Molecules. Angew. Chem. Int. Ed. Engl. 2014, 53, 11228.

${ }^{23}$ Li, Q.; Lu, J.; Boas, J. F. ; Traore, D. A. K. ; Wilce, M. C. J.; Martin, L. L.; Ueda, T.; Bond, A. M. Spontaeous Redox Synthesis and Characterization of the Tetrathiafulvalene-VanadiumSubstituted Polyoxometalate Charge-Transfer Material TTF $4\left[\mathrm{SVW}_{11} \mathrm{O}_{40}\right]$ : Comparison with the Mo Analogue. Inorg. Chem. 2014, 53, 10996.

${ }^{24}$ Barthelmes, K.; Sittig, M.; Winter, A.; Schubert, U. S. Molecular Dyads and Triads Based on Phenothiazine and p-Extended Tetrafulvalene Donors, Bis(terpyridine)ruthenium(II) Complexes, and Polyoxometalates. Eur. J. Inorg. Chem. 2017, 3698.

25 Gatard, S.; Blanchard, S.; Schollhorn, B.; Gouzerh, P.; Proust, A.; Boubekeur, K. Electroactive Benzothiazole Hydrazones and Their $\left[\mathrm{Mo}_{6} \mathrm{O}_{19}\right]^{2-}$ Derivatives: Promising Building Blocks for Conducting Molecular Materials. Chem. Eur. J. 2010, 16, 8390.

${ }^{26}$ Zhao, B.-T.; Blesa, M.-J.; Le Derf, F.; Canevet, D. ; Benhaoua, C. ; Mazari, M. ; Allain, M. ; Sallé, M. Carboxylic Acid Derivatives of Tetrathiafulvalene: Key Intermediates for the Synthesis of Redox-Active Calixarene-Based Anion Receptors. Tetrahedron 2007, 63, 10768.

${ }^{27}$ Etter, M. C. Encoding and Decoding Hydrogen-Bond Patterns of Organic Compounds. Acc. Chem. Res. 1990, 23, 120. 
${ }^{28}$ Dolbecq, A.; Fourmigué, M.; Batail, P. Synthesis and Structure of the Neutral $\pi$-donor Molecule MesTTF-COOH and of its Decarboxylated Cation Radical Salt $\left[\mathrm{Me}_{3} \mathrm{TTF}^{\bullet+}\right]\left[\mathrm{Re}_{6} \mathrm{Se}_{5} \mathrm{Cl}_{9}^{-}\right]$. Bull. Soc. Chim. Fr. 1996, 133, 83.

${ }^{29}$ Heuzé, K.; Fourmigué, M.; Batail, P. The Crystal Structure of Amide-Functionalized Ethylenedithiotetrathiafulvalenes : EDT-TTF-CONRR' (R, R' = H, Me) J. Mat. Chem. 1999, 9, 2373.

30 Mézière, C.; Fourmigué, M.; Fabre, J.-M. Efficient Synthesis of Ethylenedioxotetrathiafulvalene (EDO-TTF) and Analysis of the Role of $\mathrm{S}^{\cdots} \mathrm{S}$ van der Waals Interactions in the Crystal Chemistry of Neutral TTF Derivatives. C. R. Acad. Sci. Paris, Série IIc 2000, 3, 387.

${ }^{31}$ Ai, H.; Wang, Y.; Li, B.; Wu, L. Synthesis and Characterization of Single-Side Organically Grafted Anderson-Type Polyoxometalates. Eur. J. Inorg. Chem. 2014, 2766.

32 (a) Halpina, Y. ; Schulz, M.; Brooksc, A. C. ; Browned, W. R. ; Wallisc, J. D. ; Gonzáleze, L. ; Dayf, P. ; Vos, J. G., Electrochemistry and time dependent DFT study of a (vinylenedithio)TTF derivative in different oxidation states Electrochimica Acta 2013, 100, 188. (b) Andreu, R.; Garín, J.; Orduna, J., Electronic absorption spectra of closed and open-shell tetrathiafulvalenes: the first time-dependent density-functional study, Tetrahedron 2001, 57, 7883.

${ }^{33}$ Ashton, P. R.; Balzani, V.; Becher, J.; Credi, A.; Fyfe, M. C. T.; Mattersteig, G.; Menzer, S.; Nielsen, M. B.; Raymo, F. M.; Stoddart, J. F.; Venturi, M.; Williams, D. J. A Three-Pole Supramolecular Switch. J. Am. Chem. Soc. 1999, 121, 3951.

${ }^{34}$ (a) Wagner, K.; Byrne, R.; Zanoni, M.; Gambhir, S.; Dennany, L.; Breukers, R.; Higgins, M.; Wagner, P.; Diamond, D.; Wallace, G. G.; Officer, D. L. A Multiswitchable Poly(terthiophene) Bearing a Spiropyran Functionality: Understanding Photo- and Electrochemical Control. J. Am. Chem. Soc. 2011, 133, 5453. (b) Ivashenko, O.; van Herpt, J. T.; Feringa, B. L.; Rudolf, P.; 
Browne, W. R. Electrochemical Write and Read Functionality through Oxidative Dimerization of Spiropyran Self-Assembled Monolayers on Gold. J. Phys. Chem. C 2013, 117, 18567.

${ }^{35}$ Coe, B. J.; Harris, J. A.; Asselberghs, I.; Clays, K.; Olbrechts, G.; Persoons, A.; Hupp, J. T.; Johnson, R. C.; Coles, S. J.; Hursthouse, M. B.; Nakatani, K. Quadratic Nonlinear Optical Properties of N-Aryk Stilbazolium Dyes. Adv. Funct. Mat. 2002, 12, 110.

${ }^{36}$ Kauscher, U.; Bartels, K.; Schrader, I.; Azov, V. A.; Ravoo, B. J. Metastable Oxidation States of Tetrathiafulvalenes on the Surface of Liposomes. J. Mat. Chem. B 2015, 3, 475.

${ }^{37}$ Oudar J. L.; Chemla D. S. Hyperpolarizabilities of the Nitroanilines and their Relations to the Excited State Dipole Moment. J. Chem. Phys. 1977, 66, 2664.

${ }^{38}$ Marcoux, P. R.; Hasenknopf, B.; Vaissermann, J.; Gouzerh, P. Developing Remote Metal Binding Sites in Heteropolymolybdates. Eur. J. Inorg. Chem. 2003, 2406.

${ }^{39}$ Krejcik, M.; Danek, M.; Hartl, F. Simple Construction of Infrared Optically Transparent Thin-Layer Electrochemical Cell. J. Electroanal. Chem. 1991, 317, 179.

${ }^{40}$ Sheldrick, G. M. SADABS, Program for Scaling and Correction of Area Detector Data, University of Göttingen, Germany, 1997.

${ }^{41}$ Blessing, R. An Empirical Correction for Absorption Anisotropy. Acta Crystallogr. 1995, A51, 33 .

${ }^{42}$ Sheldrick, G. M. SHELX-TL version 5.03, Software Package for the Crystal Structure Determination, Siemens Analytical X-ray Instrument Division : Madison, WI USA, 1994.

${ }^{43}$ van der Sluis, P.; Spek, A. L. Acta Crystallogr., Sect. A. 1990, 46, 194.

${ }^{44}$ (a) Terhune, R. W.; Maker, P. D.; Savage, C. M. Measurements of Nonlinear Light Scattering. Phys. Rev. Lett. 1965, 14 (17), 681. (b) Clays, K.; Persoons, A. Hyper-Rayleigh Scattering in Solution. Phys. Rev. Lett. 1991, 66 (23), 2980. 